\title{
Tandem Diastereo- and Enantioselective Preparation of Aryl and Alkyl Cyclopropyl Carbinols with Three Adjacent Stereocenters Using Perhydrobenzoxazines and Diethylzinc
}

\author{
Rebeca Infante, ${ }^{a}$ Javier Nieto* and Celia Andrés*
}

Instituto CINQUIMA and Departamento de Química Orgánica, Facultad de Ciencias, Universidad de Valladolid, Paseo de Belén, 7, 47011 Valladolid, Spain. E-mail: javiernr@qo.uva.es

The enantio- and diastereoselective one-pot ethylation/cyclopropanation is efficiently promoted by a chiral perhydrobenzoxazine. The catalytic system tolerates a wide range of di- and trisubstituted $\alpha, \beta$ unsaturated aldehydes and has been found to be highly diastereo- and enantioselective. Enals leading to intermediates lacking allylic strain or with either $\mathrm{A}^{1,2}$ or $\mathrm{A}^{1,3}$ strain afford the corresponding syn hydroxycyclopropanes very selectively. While $\alpha$-methyl enals are successfully ethylated/cyclopropanated, the presence of bulky substituents at alpha position of the enal constitutes a limitation to the substrate scope. The use of 1,1-diiodoethane allows the obtention of the corresponding enantioenriched cyclopropylcarbinol, which bears carbon-substituents at all three positions of the ring, with good enantiocontrol, although moderate diastereoselectivity. A procedure for the asymmetric one-pot arylation/cyclopropanation of enals is proposed, which involves the use of triarylboroxin, diethylzinc and diiodomethane.

\section{Introduction}

Enantioenriched cyclopropanes constitute one of the most attractive subunits in organic chemistry, probably due to the diverse biological properties, such as enzyme inhibition, insecticidal, antifungal, herbicidal, antimicrobial, antibiotic, antibacterial, antitumor and antiviral activities, that simple cyclopropanes or with more complex functionalities present. 1 This structure is an important scaffold to elaborate more complex molecules, and it can be found in more than 4000 natural compounds and proximal 120 therapeutic agents. ${ }^{1,2}$ Additionally, due to the three-membered ring strain, these compounds can undergo an assortment of synthetically useful ring-opening reactions. ${ }^{3,4}$ For these reasons, novel and more efficient methodologies for the preparation of enantiopure cyclopropanes are continuously emerging. ${ }^{1-3,5}$ To date, the different synthetic strategies can be generally classified into three main groups. ${ }^{1 j}$ In first place, the transition metal-catalyzed decomposition of diazoalkanes has been probably one of the most studied approaches for the cyclopropanation of olefins, and very important advances in terms of stereoselectivity have been achieved in this area employing diazocompounds and chiral auxiliaries as well as chiral catalysts. ${ }^{1,6}$ More recently, a promising strategy has emerged from the organocatalysis, which allowed the synthesis of enantioenriched cyclopropanes, usually via a Michael-initiated ring closure. ${ }^{1,7}$ Another approach to the stereoselective synthesis of cyclopropanes concerns the halomethylmetal-mediated cyclopropanation reactions, which is commonly known as Simmons-Smith reaction. ${ }^{1,8}$ Although the first report by Emschwiller dates from $1929,{ }^{9}$ in which diiodomethane was reacted with zinc to give iodomethylzinc species, more than 30 years were necessary for the introduction of the cyclopropanation of alkenes with diiodomethane in the presence of activated zinc by Simmons and Smith. ${ }^{10}$ Since then, different alternative procedures for the preparation of a variety of metal carbenoid species have been 
developed, and one of the most popular methods is the alkyl exchange of diethylzinc with diiodomethane. $^{1 \mathrm{f}}$

The foremost advantages that have contributed to the attractiveness of Simmons-Smith reagents are associated to a broad substrate generality, a wide tolerance of functional groups and the chemoselectivity with respect to alkene geometry. In addition, proximal oxygen atoms have been found to enhance the syn-directing effect and a superior reactivity has been demonstrated when an allylic alcohol was employed as substrate instead of unfunctionalized alkenes. ${ }^{1 f, 1 j}$ The stereochemistry of this transformation has been explained through a 'butterfly-type' transition state. ${ }^{1 a, 11,12}$ The first stereoselective cyclopropanation of acyclic allylic alcohols by means of Simmons-Smith reagent was performed by Pereyre in $1978,{ }^{13}$ who attained high syn selectivities for (Z)-disubstituted olefins but very poor for the (E)-isomers. In this context, Charette demonstrated that the nature of the carbenoid was very important in order to obtain similar stereocontrol for both (E)- and (Z)-disubstituted allylic alcohols. ${ }^{1 f, 14}$ However, the highly stereoselective cyclopropanation of acyclic trisubstituted allylic alcohols has proven to be more challenging, because the allylic strains in the transition-state and the different protective groups of the alcohol, as well as the reagent, play an important role. ${ }^{\text {If }}$

Despite these magnificent features, the enantiocontrol of Simmons-Smith-type cyclopropanations of olefins and allylic alcohols has been found more difficult in contrast to the two other approaches (organocatalysis and decomposition of diazocompounds), which lead to enantioenriched cyclopropanes with high selectivity. Nevertheless some exceptions are gradually arising, ${ }^{15,16}$ one of which is constituted by the work developed by Walsh et al., who have described the first highly stereoselective one-pot synthesis of a large family of cyclopropanes from achiral precursors with up to four contiguous stereocenters. 16 The intermediate allylic alkoxides were prepared by enantioselective alkyl and vinylzinc additions to carbonyls promoted by (-)-MIB as chiral catalyst.

In spite of these numerous high-quality contributions, curiously no related examples of the stereoselective preparation of cyclopropyl(phenyl)methanols through one-pot phenylation/cyclopropanation of $\alpha, \beta$-unsaturated aldehydes were studied.

In previous works we have reported the utility of chiral perhydro-1,3-benzoxazines in different diastereoselective cyclization processes $^{17}$ and recently we have shown that conformationally restricted perhydro-1,3-benzoxazines behabe as excellent ligands for the enantioselective addition of organozinc reagents to carbonyl compounds. ${ }^{18}$ Encouraged by the excellent results obtained in the asymmetric alkylation and arylation of aldehydes promoted by our perhydrobenzoxazine 1 (Scheme 1), ${ }^{19}$ we decided to tackle the challenging preparation of cyclopropyl(phenyl)methanols in a tandem way employing the in situ generated EtZnPh. Previously, we planned to study more extensively the scope and limitations of ethylation/cyclopropanation of a variety of acyclic di- and trisubstituted $\alpha, \beta$-unsaturated aldehydes using the methodology developed by Walsh, and also to verify whether our ligand behaves similarly to (-)-MIB.

\section{Results and discussion}

The asymmetric ethylation/cyclopropanation of $\beta$-phenylcinnamaldehyde to yield the corresponding (cyclopropyl)propan-1-ol, in the presence of 4 mol\% of perhydrobenzoxazine 1 (Scheme 1), ${ }^{19}$ was chosen as a model reaction to examine the reaction conditions. As we commented before, the reaction takes place in two steps, but in a one-pot way. While the first 
step involves the enantioselective ethylation of the aldehyde by Et2Zn addition promoted by the chiral inductor 1, the second step concerns the cyclopropanation of the intermediate allylic alkoxide employing the highly reactive reagent $\mathrm{CF}_{3} \mathrm{CH}_{2} \mathrm{OZnCH}_{2} \mathrm{I}$, ${ }^{6 a}$ generated in situ from $\mathrm{Et}_{2} \mathrm{Zn}, \mathrm{CF}_{3} \mathrm{CH}_{2} \mathrm{OH}$ and $\mathrm{CH}_{2} \mathrm{I}_{2}$. For the ethylation step, we considered the best reaction conditions established in a reported work, ${ }^{18 a}$ which involved the use of 2 equivalents of diethylzinc in toluene at room temperature. Concerning the cyclopropanation step several reaction parameters, such as temperature, solvent and reaction time, were investigated.

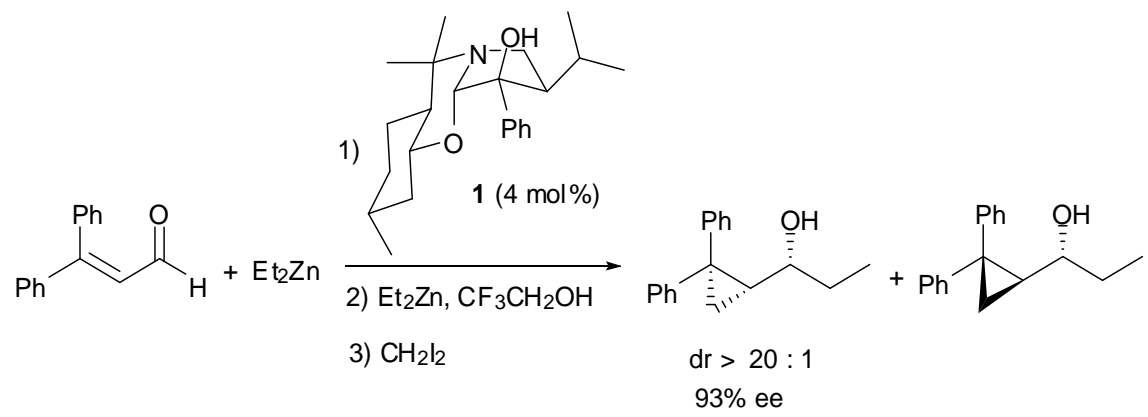

Scheme 1. Model reaction to establish the optimal conditions using the perhydrobenzoxazine 1

Surprisingly, we found that the efficiency of the catalytic system in terms of stereocontrol was maintained very high with independence of the solvent employed (toluene, hexane or a mixture of both) and the reaction temperature $\left(-20^{\circ} \mathrm{C}, 0^{\circ} \mathrm{C}\right.$ or $\left.25^{\circ} \mathrm{C}\right)$. The target syn hydroxy cyclopropane was obtained in all cases with excellent diastereoselection and $93 \%$ ee, and the chemical yields were higher when toluene was employed as solvent at room temperature. Finally, the reaction time was fixed to $24 \mathrm{~h}$ in order to obtain an almost quantitative yield $(92 \%)$.

Once the optimized conditions for the one-pot ethylation/cyclopropanation were confirmed, the substrate scope was explored and a variety of acyclic di- and trisubstituted enals were considered. The results for the known (entries 1,5) and novel hydroxy cyclopropanes (entries 2-4, 6-8) are summarized in Table 1.

It is noteworthy that the transformations afforded only a single diastereoisomer in each case, which was determined by $1 \mathrm{H}-\mathrm{NMR}$, independently of the allylic strains exhibited by the intermediate alkoxide: A1,2 strain (entries 1, 2), A1,3 strain (entries 3, 4), or neither A1,2 nor A1,3 strain (entries 5-8). To our delight, all reactions carried out on trisubstituted $\alpha, \beta$ unsaturated aldehydes allowed the obtention of the corresponding syn hydroxy cyclopropanes in excellent yields and total diastereoselection with high enantioselectivities for different substitution patterns (entries 1-4). Nevertheless, an exception to this behavior was the transformation of aldehyde $\mathbf{2 b}$ (entry 2), which leads to an intermediate allylic alkoxyde with A1,2 strain. The corresponding hydroxy cyclopropane $\mathbf{3 b}$ was obtained in absolute diastereoselectivity but in low yield and with moderate optical purity, while the main product detected by $1 \mathrm{H}-\mathrm{NMR}$ in the crude reaction mixture was the corresponding allylic alcohol. Probably, as a result of steric hindrance and the electronic effect. The $\mathrm{Br}$ is very deactivating, slowing the cyclopropanation while the carbenoid decomposes. On the contrary, when the reaction was carried out on $\alpha$-methyl-trans-cinnamaldehyde $\mathbf{2 a}\left(\mathrm{R}^{3}=\mathrm{Me}\right.$, entry 1$)$, the hydroxy cyclopropane 3a was provided quantitatively in $91 \%$ ee. 
Good to high enantioselectivities were reached when no allylic strains were present on the acyclic disubstituted allylic alkoxides derived from aldehydes $2 e-h\left(R^{1}=R^{3}=H, R^{2} \neq H\right.$, entries 5-8). An alkoxy group in ortho- and para- positions of phenyl ring in $\mathrm{R}^{2}$ resulted in a decrease of ee (entries 6,7 ), but interestingly the chemical yield of $3 \mathrm{f}$ was high, which might be attributed to additional interactions with the o-methoxy substituent in the transition-state. Moreover, 2-furylacrylaldehyde $\mathbf{2 h}$ (entry 8 ) was as well tolerated as trans-cinnamaldehyde $\mathbf{2 e}$ (entry 5) under our optimal conditions, affording selectively the syn hydroxy cyclopropane with good yield and $90 \%$ ee..

Table 1. One-pot catalytic asymmetric ethylation/cyclopropanation of several trisubstituted and disubstituted $\alpha, \beta$-unsaturated aldehydes in the presence of $\mathbf{1}$.

\begin{tabular}{|c|c|c|c|c|c|c|c|c|}
\hline \multirow[b]{2}{*}{$\overline{\text { Entry }^{a}}$} & \multirow[t]{2}{*}{$\underbrace{\mathrm{R}^{1}}$} & & $\begin{array}{ll}\mathrm{Zn} & \frac{\mathbf{1}(4 \mathrm{mc}}{\text { 2) } \mathrm{Et}_{2} \mathrm{Zn}, \mathrm{C}} \\
\text { 3) } \mathrm{CH}_{2} \mathrm{I}_{2}, \mathrm{r}\end{array}$ & ${ }_{2} \mathrm{OH}$ & $\overrightarrow{0 \mathrm{~min}}$ & $R^{1}$ & $\mathrm{OH}$ & \\
\hline & & $\mathrm{R}^{1}$ & $\mathrm{R}^{2}$ & $\mathrm{R}^{3}$ & 3 & $\begin{array}{l}\text { Yield } \\
(\%)^{b}\end{array}$ & $\begin{array}{l}\mathrm{dr} \\
(\text { syn:anti })^{c}\end{array}$ & $\begin{array}{l}\text { ee } \\
(\%)^{d}\end{array}$ \\
\hline 1 & $2 a$ & $\mathrm{H}$ & $\mathrm{Ph}$ & $\mathrm{Me}$ & 3a & 97 & $>20: 1$ & $91^{e}$ \\
\hline 2 & $2 b$ & $\mathrm{H}$ & $\mathrm{Ph}$ & $\mathrm{Br}$ & $3 b$ & 37 & $>20: 1$ & 78 \\
\hline 3 & $2 c$ & $\mathrm{Me}$ & $\mathrm{Ph}$ & $\mathrm{H}$ & $3 c$ & 94 & $>20: 1$ & 90 \\
\hline 4 & 2d & $\mathrm{Ph}$ & $\mathrm{Ph}$ & $\mathrm{H}$ & 3d & 92 & $>20: 1$ & 93 \\
\hline 5 & $2 e$ & $\mathrm{H}$ & $\mathrm{Ph}$ & $\mathrm{H}$ & $3 e$ & 90 & $>20: 1$ & $90^{e}$ \\
\hline 6 & $2 f$ & $\mathrm{H}$ & $o-\mathrm{MeOC}_{6} \mathrm{H}_{4}$ & $\mathrm{H}$ & $3 f$ & 93 & $>20: 1$ & 84 \\
\hline 7 & $2 g$ & $\mathrm{H}$ & $p-\mathrm{MeOC}_{6} \mathrm{H}_{4}$ & $\mathrm{H}$ & $3 g$ & 82 & $>20: 1$ & 80 \\
\hline 8 & $2 \mathrm{~h}$ & $\mathrm{H}$ & 2-Furyl & $\mathrm{H}$ & $3 \mathbf{h}$ & 85 & $>20: 1$ & 90 \\
\hline
\end{tabular}

${ }^{a} \mathbf{1} / \mathrm{ZnEt}_{2} / \mathrm{Aldehyde}_{\mathrm{ZnEt}} / \mathrm{CF}_{3} \mathrm{CH}_{2} \mathrm{OH} / \mathrm{CH}_{2} \mathrm{I}_{2}=0.04 / 2 / 1 / 2 / 2 / 2 .{ }^{b}$ Yield of isolated product after purification by flash chromatography. ${ }^{c}$ Only a single diastereomer was detected in the crude ${ }^{1} \mathrm{H}$-NMR spectra in each case. ${ }^{d}$ Determined by HPLC employing chiral columns (AS-H, OD, AD and AD-H). ${ }^{e}$ Configuration was assigned by comparing ${ }^{1} \mathrm{H}-\mathrm{NMR}$ spectra and the sign of specific rotation with reported values (see supporting information for further details).

Considering the poor yield obtained with $\mathbf{2 b}$ (entry 2), we were interested in studying the influence exerted by a phenyl group at alpha position of the enal, so aldehydes $\mathbf{2} \mathbf{i}-\mathbf{k}$ were subjected to the alkylation/cyclopropanation protocol (Scheme 2). The results indicated a very low yield of the hydroxy cyclopropane in $24 \mathrm{~h}$, less than $10 \%$, independently of the nature of the $\mathrm{R}^{2}$ substitutent (alkyl or aryl). In all cases the main products isolated were the corresponding enantioenriched allylic alcohol, and total absence of the starting aldehydes $\mathbf{2 i - k}$ was observed. An increase of the cyclopropanation reaction time to $50 \mathrm{~h}$ resulted in similar conversions. So summing up, while a methyl substituent is well tolerated at alpha position of the enal, the presence of either phenyl or a voluminous group at this position constitutes one limitation for these one-pot reactions.

In order to increase the substrate generality and bearing in mind that 1,2,3-substituted cyclopropanes belong to a large family of pharmacologically active and natural compounds, we tested the one-pot ethylation/cyclopropanation reaction employing a different diiodide (1,1diiodoethane) ${ }^{20}$ The results are shown in the Scheme 3. 
Although in this way the creation of an additional stereocenter might complicate the diastereocontrol a priori, good values were reached in this term. Furthermore the enantioselectivity of the reaction was maintained high, while the yield was moderate. Concerning the stereochemical assignment, the value of the $\mathrm{H}-\mathrm{H}$ coupling constant between the two hydrogens attached to the cyclopropane ring (CHMe - R'CHR, $J=5.7 \mathrm{~Hz}$ ) and a NOESY experiment suggested a trans disposition between each other for the major diastereomer $\mathbf{4 d} .^{16 \mathrm{~b}}$

Taking into account the excellent precedents in arylation of aldehydes promoted by our ligand, a new protocol for the synthesis of cyclopropyl(phenyl)methanols through tandem phenylation/cyclopropanation of acyclic di- and trisubstituted $\alpha, \beta$-unsaturated aldehydes using the ligand 1 as chirality source and EtZnPh species generated in situ from triphenylboroxin and diethylzinc was developed. The results are collected in Table 2

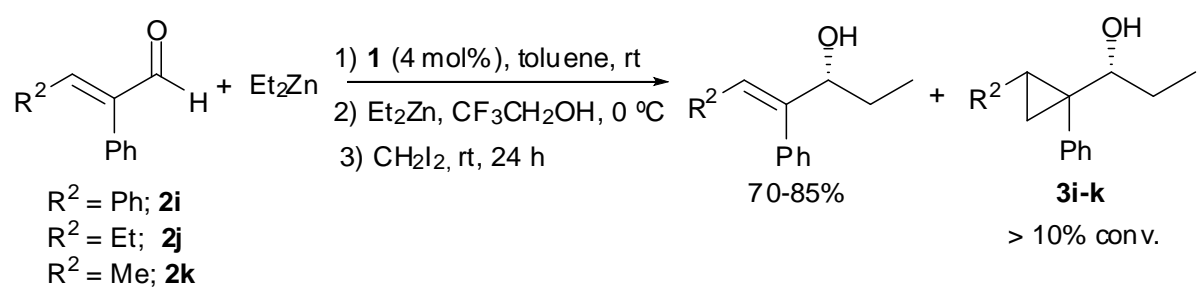

Scheme 2. Ethylation/cyclopropanation of $\alpha$-phenyl enals

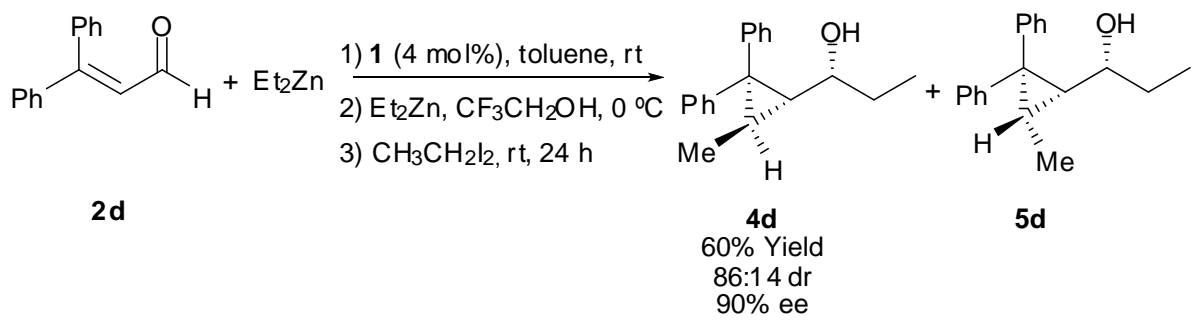

Scheme 3. One-pot method for the synthesis of 1,2,3-substituted cyclopropanes from enals

Initially, the phenyl(ethyl)zinc species was generated in situ through transmetallation between triphenylboroxin and diethylzinc in toluene at $60^{\circ} \mathrm{C}$ for $30 \mathrm{~min},{ }^{21}$ and subsequently the addition of the aldehyde to the reaction mixture in the previously reported optimal conditions ${ }^{18 \mathrm{~b}}$ was carried out. Next, instead of quenching the zinc alkoxide, the cyclopropanation of the double bound was performed at room temperature in light exclusion without the need of removing the boron species. The quantities of the reagents for the cyclopropanation step were adequate in order to obtain the best yields. As can be regarded in table 2, although variable diastereoselectivities were found in the tandem phenylation/cyclopropanation, the desired products were afforded in moderate to good yields for the four essayed substrates. Complete diastereoinduction was perceived when the reaction was run over the trisubstituted aldehyde $\mathbf{2 d}$ (entry 2), which leads to A1,3 strain in the transition-state, nevertheless the ee reached with such substrate was poor. High enantioselectivities were obtained for the two diastereoisomers isolated in the reaction carried out over a different trisubstituted aldehyde ( $2 \mathrm{a}$, entry 1 ), whose corresponding allylic alkoxide presents A1,2 strain. However, the diastereoselectivity was not as high as the corresponding ethylated hydroxycyclopropane counterpart (see entry 1 in Table 1 vs Table 2). Unafortunately, diastereoselectivity was not improved by adding cosolvents such as 
hexane or dichloromethane and a decrease in reaction temperature at $0{ }^{\circ} \mathrm{C}$ only results in a significant decrease in chemical yield. Screning other zinc carbenoids, such as $\mathrm{CF}_{3} \mathrm{CO}_{2} \mathrm{ZnCH}_{2} \mathrm{I}$ or $\mathrm{EtZnCH}_{2} \mathrm{I}$ was also unsuccessful.

Table 2. One-pot catalytic asymmetric phenylation/cyclopropanation of several $\alpha, \beta$-unsaturated aldehydes in the presence of $\mathbf{1}$ and triphenylboroxin as aryl source.

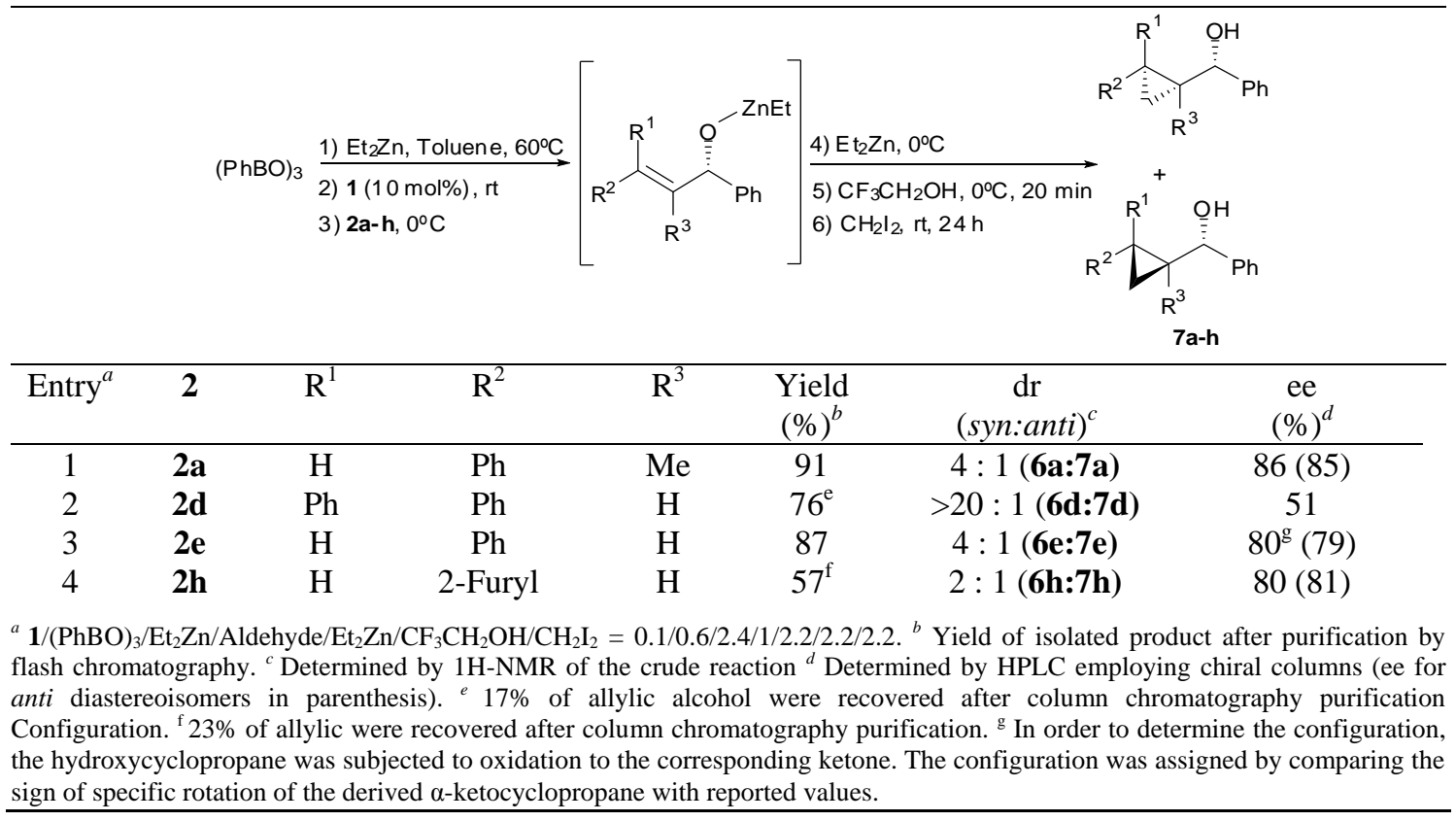

The disubstituted $\alpha, \beta$-unsaturated aldehydes $\mathbf{2 e}$ and $\mathbf{2 h}$ (aromatic and heterocyclic respectively, entries 3,4) were also well tolerated by our protocol and resulted in great competitive values in terms of optical purity of the products, albeit moderate diastereoselection was achieved.

Finally, the transformation of the purified enantioenriched hydroxy cyclopropane $\mathbf{6 e}$ into the known $\alpha$-ketocyclopropane 8e with PCC in DCM at rt allowed the confirmation of the cyclopropane ring stereochemistry by comparison of the sign of the specific rotation with reported data (Scheme 4). ${ }^{22}$

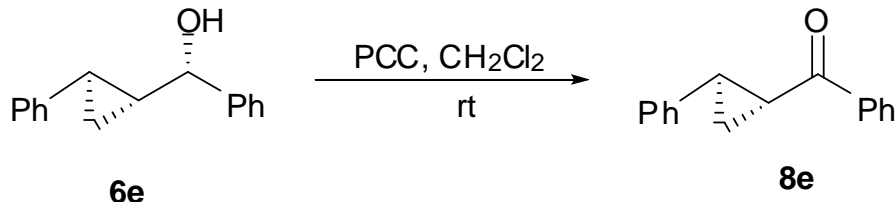

Scheme 4. Transformation of hydroxycyclopropane $6 \mathrm{e}$ to $8 \mathrm{e}$ 


\section{Conclusions}

To sum up, a set of some new and known (cyclopropyl)propan-1-ols could be prepared in very good yields with total diastereoselectivity and high enantiocontrol independently of the substitution pattern of the $\alpha, \beta$-unsaturated aldehydes by ethylation/cyclopropanation employing the ligand 1 as chiral source. An extended study was carried out to elucidate the reach and limitations of this reaction, which not only permits the use of aldehydes possessing A1,2 and A1,3 strain but also tolerates well strain-lacking substrates. Besides, we verified experimentally that a bulky substituent at the alpha position of the enal still constitutes an unresolved aspect of this reaction. In order to confirm the generality of the method, a hydroxy cyclopropane with carbon-substituents at all positions of the ring was isolated for the first time in a one-pot way in a reasonable yield with high stereoselection. Finally, a novel protocol for the preparation of enantioenriched cyclopropyl(phenyl)methanols through tandem arylation/cyclopropanation of $\alpha, \beta$-unsaturated aldehydes was successfully developed. This procedure involved the in situ generated $\mathrm{PhZnEt}$, from triphenylboroxin and diethylzinc, and it avoids the need for removing the boron byproducts.

\section{Experimental section}

All reactions were carried out in anhydrous solvents under argon atmosphere in flamedried glassware by means of Schlenk techniques. 1H-NMR (300 MHz or $400 \mathrm{MHz}$ ) and 13CNMR (75 MHz or $100 \mathrm{MHz}$ ) spectra were recorded in $\mathrm{CDCl} 3$. Chemical shifts for protons are reported in ppm from tetramethylsilane with the residual $\mathrm{CHCl} 3$ resonance as internal reference. Chemical shifts for carbons are reported in ppm from tetramethylsilane and are referenced to the carbon resonance of the solvent. Data are reported as follows: chemical shift, multiplicity ( $\mathrm{s}=$ singlet, $\mathrm{d}=$ doublet, $\mathrm{t}=$ triplet, $\mathrm{q}=$ quartet, $\mathrm{sp}=$ septet, $\mathrm{m}=$ =multiplet, $\mathrm{br}=$ broad), coupling constants in Hertz, and integration. Specific rotations were measured using a 5-mL cell with a 1$\mathrm{dm}$ path length, and a sodium lamp, and concentration is given in $\mathrm{g}$ per $100 \mathrm{~mL}$. Flash chromatography was carried out using silica gel (230-240 mesh). Chemical yields refer to pure isolated substances. TLC analysis was performed on glass-backed plates coated with silica gel 60 and an F254 indicator, and visualized by either UV irradiation or by staining with I2 or phosphomolybdic acid solution. Chiral HPLC analysis was performed using a Daicel Chiralcel OD Column, Chiralpak AD-H or Chiralpak AS-H. UV detection was monitored at $220 \mathrm{~nm}$ or at $254 \mathrm{~nm}$. High resolution mass spectrometry analysis (HRMS) were performed by a cuadrupole spectrometer with TOF analyzer.

Unless otherwise indicated, all compounds were purchased from commercial sources and used as received. Aldehydes $2 \mathrm{c}$ and and $2 \mathrm{i}$ were synthesized from commercially available ethyl trans- $\beta$-methylcinnamate and (Z)-2,3-diphenyl-2-propenoic acid respectively by reduction with LiAlH4 followed by Swern oxidation of the corresponding alcohol.23 Racemic hydroxycyclopropanes were synthesized according to general procedure employing racemic 3hydroxy-N-methylpyrrolidine as ligand. 1,1-Diiodoethane was prepared according to literature procedure.20 Triphenylboroxin was freshly prepared by heating the corresponding phenylboronic acid for $8 \mathrm{~h}$ at $110{ }^{\circ} \mathrm{C}$ in a conventional oven and used without further purification.24Ligand 1 was prepared according to reported procedures.19

Compounds $\mathbf{5 d}$ and $\mathbf{6 h}$ could not be obtained pure after flash chromatography 
General procedure for the enantioselective one-pot synthesis of (cyclopropyl)propan-1-ols from $\alpha, \beta$-unsaturated aldehydes and diethylzinc.

To a flame-dried, argon-purged flask containing the ligand $(7.1 \mathrm{mg}, 0.02 \mathrm{mmol}, 4$ mol\%) and dry toluene $(1 \mathrm{~mL})$ was added a $1 \mathrm{M}$ solution of diethylzinc in hexane $(1 \mathrm{~mL}, 1$ mmol) at room temperature. After stirring for $10 \mathrm{~min}$, a solution of the corresponding $\alpha, \beta$ unsaturated aldehyde $(0.5 \mathrm{mmol})$ in dry toluene $(0.5 \mathrm{~mL})$ was added and allowed to react at room temperature (TLC, 30-45 min). Next, the reaction mixture was cooled to $0^{\circ} \mathrm{C}$ with light exclusion and $\mathrm{Et}_{2} \mathrm{Zn}(1 \mathrm{~mL}, 1 \mathrm{mmol})$ was added. Dropwise addition of $\mathrm{CF}_{3} \mathrm{CH}_{2} \mathrm{OH}(73 \mu \mathrm{L}, 1$ mmol) was performed over $20 \mathrm{~min}$. After stirring at $0^{\circ} \mathrm{C}$ for $20 \mathrm{~min}, \mathrm{CH}_{2} \mathrm{I}_{2}(80 \mu \mathrm{L}, 1 \mathrm{mmol})$ or $\mathrm{CH}_{3} \mathrm{CHI}_{2}$ (282 $\mathrm{mg}, 1 \mathrm{mmol}$ ) was added and the reaction mixture was stirred at room temperature for $24 \mathrm{~h}$. Finally, the reaction was quenched by dropwise addition of an aqueous ammonium chloride solution. The organic layer was separated and the aqueous phase was extracted with $\mathrm{CH}_{2} \mathrm{Cl}_{2}(3 \times 10 \mathrm{~mL})$. The combined organic layers were washed with brine and dried over anhydrous $\mathrm{MgSO}_{4}$. The solvents were removed under reduced pressure and the residue was purified by column chromatography on silica gel using mixtures of hexane/EtOAc as eluent. The ee values were determined by HPLC on a chiral stationary phase.

(R)-1-((1R,2S)-1-methyl-2-phenylcyclopropyl)propan-1-ol (3a). This compound was obtained from $(E)$ - $\alpha$-methylcinnamaldehyde $(71 \mu \mathrm{L}, 0.5 \mathrm{mmol})$ and $\mathrm{CH}_{2} \mathrm{I}_{2}(80 \mu \mathrm{L}, 1 \mathrm{mmol})$, and purified by flash chromatography (ethyl acetate/hexane $=1 / 20)$. Colorless oil. $[\alpha]_{\mathrm{D}}{ }^{20}-20.0(c$ 1.0, $\mathrm{CHCl}_{3}$ ), (lit. ${ }^{16 \mathrm{a}}[\alpha]_{\mathrm{D}}{ }^{20}+10.5\left(c 1.2, \mathrm{CHCl}_{3}\right) .{ }^{1} \mathrm{H}-\mathrm{NMR}\left(300 \mathrm{MHz}, \mathrm{CDCl}_{3}\right) \delta 0.81(\mathrm{~s}, 3 \mathrm{H})$, $0.85-0.99(\mathrm{~m}, 2 \mathrm{H}), 1.09(\mathrm{t}, J=7.5 \mathrm{~Hz}, 3 \mathrm{H}), 1.53-1.88(\mathrm{~m}, 3 \mathrm{H}), 2.03\left(\mathrm{dd}, J_{l}=8.7 \mathrm{~Hz}, J_{2}=6.0\right.$ $\mathrm{Hz}, 1 \mathrm{H}), 2.95\left(\mathrm{dd}, J_{I}=7.9 \mathrm{~Hz}, J_{2}=5.5 \mathrm{~Hz}, 1 \mathrm{H}\right), 7.17-7.26(\mathrm{~m}, 3 \mathrm{H}), 7.27-7.37(\mathrm{~m}, 2 \mathrm{H}) .{ }^{13} \mathrm{C}-$ NMR (75 MHz, $\left.\mathrm{CDCl}_{3}\right) \delta 11.0\left(\mathrm{CH}_{3}\right), 12.3\left(\mathrm{CH}_{3}\right), 16.2\left(\mathrm{CH}_{2}\right), 27.0\left(\mathrm{CH}_{2}\right), 27.0(\mathrm{CH}), 27.7(\mathrm{C})$, $81.8(\mathrm{CH}), 125.8(\mathrm{CH}), 127.9(2 \mathrm{CH}), 128.9(2 \mathrm{CH}), 138.6(\mathrm{C})$. IR (neat) vmax 3370, 3060, 3030, 2960, 2935, 2875, 1605, 1500, 1450, 1080, 1015, 955, 775, 740, 700, $600 \mathrm{~cm}^{-1}$. HPLC (Chiralcel OD, hexane:isopropanol $=99: 01,1 \mathrm{~mL} / \mathrm{min}, \lambda=220 \mathrm{~nm}$ ) $\mathrm{t}_{\mathrm{R}}=16.3 \mathrm{~min}$ for enantiomer $(S)-1-(1 S, 2 R), \mathrm{t}_{\mathrm{R}}=17.3 \mathrm{~min}$ for enantiomer $(R)-1-(1 R, 2 S)$. Configuration was assigned by comparing the ${ }^{1} \mathrm{H}$ - and ${ }^{13} \mathrm{C}$-NMR spectra and sign of optical rotation with literature data. $^{16 a}$

(R)-1-((1S,2S)-1-bromo-2-phenylcyclopropyl)propan-1-ol (3b). This compound was obtained from (Z)- $\alpha$-bromocinnamaldehyde $(105 \mathrm{mg}, 0.5 \mathrm{mmol})$ and $\mathrm{CH}_{2} \mathrm{I}_{2}(80 \mu \mathrm{L}, 1 \mathrm{mmol})$, and purified by flash chromatography (ethyl acetate/hexane $=1 / 20$ ). Colorless oil. $[\alpha]_{\mathrm{D}}{ }^{20}-12.6$ (c 0.7, $\mathrm{CHCl}_{3}$ ). ${ }^{1} \mathrm{H}-\mathrm{NMR}\left(300 \mathrm{MHz}, \mathrm{CDCl}_{3}\right) \delta 1.09(\mathrm{t}, J=7.5 \mathrm{~Hz}, 3 \mathrm{H}), 1.51-1.68(\mathrm{~m}, 2 \mathrm{H})$, $1.71-1.87(\mathrm{~m}, 2 \mathrm{H}), 1.94(\mathrm{~d}, J=7.7 \mathrm{~Hz}, 1 \mathrm{H}), 2.21\left(\mathrm{dd}, J_{l}=9.9 \mathrm{~Hz}, J_{2}=7.5 \mathrm{~Hz}, 1 \mathrm{H}\right), 2.96\left(\mathrm{dt}, J_{1}\right.$ $\left.=7.7 \mathrm{~Hz}, J_{2}=5.5 \mathrm{~Hz}, 1 \mathrm{H}\right), 7.18-7.41(\mathrm{~m}, 5 \mathrm{H}) .{ }^{13} \mathrm{C}-\mathrm{NMR}\left(75 \mathrm{MHz}, \mathrm{CDCl}_{3}\right) \delta 10.4\left(\mathrm{CH}_{3}\right), 19.6$ $\left(\mathrm{CH}_{2}\right), 27.9(\mathrm{CH}), 29.0\left(\mathrm{CH}_{2}\right), 50.1(\mathrm{C}), 80.8(\mathrm{CH}), 126.9(\mathrm{CH}), 128.0(2 \mathrm{CH}), 128.9(2 \mathrm{CH})$, 136.9 (C). IR (neat) vmax 3370, 3030, 2965, 2935, 2880, 1605, 1500, 1455, 1095, 1040, 1030, 980, 770, 740, 695, 605, $530 \mathrm{~cm}^{-1}$. HRMS calcd for $\mathrm{C}_{12} \mathrm{H}_{15} \mathrm{BrO}+\mathrm{Na}^{+}, 277.0198$; found, 277.0217. HPLC (Chiralcel OD, hexane:isopropanol $=98: 02,1 \mathrm{~mL} / \mathrm{min}, \lambda=220 \mathrm{~nm}$ ) $t_{\mathrm{R}}=20.6$ $\min$ for enantiomer $(S)-1-(1 R, 2 R), \mathrm{t}_{\mathrm{R}}=24.8 \mathrm{~min}$ for enantiomer $(R)-1-(1 S, 2 S)$.

$(\boldsymbol{R})$-1-((1R,2R)-2-methyl-2-phenylcyclopropyl)propan-1-ol (3c). This compound was obtained from (E)-3-phenylbut-2-enal $(73 \mathrm{mg}, 0.5 \mathrm{mmol})$ and $\mathrm{CH}_{2} \mathrm{I}_{2}(80 \mu \mathrm{L}, 1 \mathrm{mmol})$, and purified by flash chromatography (ethyl acetate/hexane $=1 / 20)$. Colorless oil. $[\alpha]_{\mathrm{D}}{ }^{20}-34.5(c$ 
1.4, $\left.\mathrm{CHCl}_{3}\right) .{ }^{1} \mathrm{H}-\mathrm{NMR}\left(300 \mathrm{MHz}, \mathrm{CDCl}_{3}\right) \delta 0.73(\mathrm{~m}, 1 \mathrm{H}), 1.09(\mathrm{t}, J=7.5 \mathrm{~Hz}, 3 \mathrm{H}), 1.16-1.24$ (m, 2H), $1.44(\mathrm{~s}, 3 \mathrm{H}), 1.71-1.84(\mathrm{~m}, 3 \mathrm{H}), 3.31-3.48(\mathrm{~m}, 1 \mathrm{H}), 7.16-7.23(\mathrm{~m}, 1 \mathrm{H}), 7.25-7.36$ $(\mathrm{m}, 4 \mathrm{H}) .{ }^{13} \mathrm{C}-\mathrm{NMR}\left(75 \mathrm{MHz}, \mathrm{CDCl}_{3}\right) \delta 9.9\left(\mathrm{CH}_{3}\right), 18.5\left(\mathrm{CH}_{2}\right), 21.4\left(\mathrm{CH}_{3}\right), 25.3(\mathrm{C}), 30.9$ $\left(\mathrm{CH}_{2}\right), 32.2(\mathrm{CH}), 74.0(\mathrm{CH}), 125.8(\mathrm{CH}), 127.0(2 \mathrm{CH}), 128.3(2 \mathrm{CH}), 147.5(\mathrm{C})$. IR (neat) vmax 3355, 3060, 3025, 2965, 2930, 2875, 1605, 1495, 1445, 1045, 1025, 960, 760, 700, 590, 540 $\mathrm{cm}^{-1}$ HRMS calcd for $\mathrm{C}_{13} \mathrm{H}_{18} \mathrm{O}+\mathrm{Na}^{+}, 213.1250$; found, 213.1250. HPLC (Chiralpak AD-H, hexane:isopropanol $=90: 10,1 \mathrm{~mL} / \mathrm{min}, \lambda=220 \mathrm{~nm}) \mathrm{t}_{\mathrm{R}}=5.4 \mathrm{~min}$ for enantiomer $(R)-1-(1 R, 2 R)$, $\mathrm{t}_{\mathrm{R}}=6.2$ min for enantiomer $(S)-1-(1 S, 2 S)$.

(R)-1-((R)-2,2-diphenylcyclopropyl)propan-1-ol (3d). This compound was obtained from $\beta$-phenylcinnamaldehyde (104 mg, $0.5 \mathrm{mmol})$ and $\mathrm{CH}_{2} \mathrm{I}_{2}(80 \mu \mathrm{L}, 1 \mathrm{mmol})$, and purified by flash chromatography (ethyl acetate/hexane $=1 / 15)$. Colorless oil. $[\alpha]_{\mathrm{D}}{ }^{20}-103.1\left(c 2.2, \mathrm{CHCl}_{3}\right)$. ${ }^{1} \mathrm{H}-\mathrm{NMR}\left(300 \mathrm{MHz}, \mathrm{CDCl}_{3}\right) \delta 0.98(\mathrm{t}, J=7.4 \mathrm{~Hz}, 3 \mathrm{H}), 1.27\left(\mathrm{dd}, J_{l}=8.9 \mathrm{~Hz}, J_{2}=4.8 \mathrm{~Hz}, 1 \mathrm{H}\right)$, $1.58(\mathrm{~s}, 1 \mathrm{H}), 1.63-1.74(\mathrm{~m}, 2 \mathrm{H}), 1.74-1.86(\mathrm{~m}, 1 \mathrm{H}), 1.91\left(\mathrm{dt}, J_{1}=8.5 \mathrm{~Hz}, J_{2}=6.0 \mathrm{~Hz}, 1 \mathrm{H}\right)$, $2.96\left(\mathrm{td}, J_{1}=8.1 \mathrm{~Hz}, J_{2}=3.5 \mathrm{~Hz}, 1 \mathrm{H}\right), 7.16-7.29(\mathrm{~m}, 2 \mathrm{H}), 7.29-7.43(\mathrm{~m}, 8 \mathrm{H}) .{ }^{13} \mathrm{C}-\mathrm{NMR}(75$ $\left.\mathrm{MHz}, \mathrm{CDCl}_{3}\right) \delta 9.9\left(\mathrm{CH}_{3}\right), 17.0\left(\mathrm{CH}_{2}\right), 29.8\left(\mathrm{CH}_{2}\right), 31.6(\mathrm{CH}), 35.7(\mathrm{C}), 72.8(\mathrm{CH}), 125.9(\mathrm{CH})$, $126.4(\mathrm{CH}), 128.1(2 \mathrm{CH}), 128.2(2 \mathrm{CH}), 128.3(2 \mathrm{CH}), 129.8(2 \mathrm{CH}), 141.0(\mathrm{C}), 146.4(\mathrm{C}) . \mathrm{IR}$ (neat) vmax 3345, 3060, 3025, 2960, 2925, 2875, 1600, 1495, 1445, 1040, 1025, 955, 770, 755, $695,630,615,545 \mathrm{~cm}^{-1}$. HRMS calcd for $\mathrm{C}_{18} \mathrm{H}_{20} \mathrm{O}+\mathrm{Na}^{+}$, 275.1406; found, 275.1401. HPLC (Chiralcel OD, hexane:isopropanol $=99: 01,1 \mathrm{~mL} / \mathrm{min}, \lambda=220 \mathrm{~nm}$ ) $\mathrm{t}_{\mathrm{R}}=23.2 \mathrm{~min}$ for enantiomer $(R)-1-(R), \mathrm{t}_{\mathrm{R}}=26.1 \mathrm{~min}$ for enantiomer $(R)-1-(R)$.

(R)-1-((1R,2R)-2-phenylcyclopropyl)propan-1-ol (3e). This compound was obtained from $(E)$-cinnamaldehyde $(63 \mu \mathrm{L}, 0.5 \mathrm{mmol})$ and $\mathrm{CH}_{2} \mathrm{I}_{2}(80 \mu \mathrm{L}, 1 \mathrm{mmol})$, and purified by flash chromatography (ethyl acetate/hexane $=1 / 15)$. Colorless oil. $[\alpha]_{\mathrm{D}}{ }^{20}-66.2\left(c 0.6, \mathrm{CHCl}_{3}\right) .{ }^{1} \mathrm{H}-$ NMR $\left(300 \mathrm{MHz}, \mathrm{CDCl}_{3}\right) \delta 0.84-1.08(\mathrm{~m}, 2 \mathrm{H}), 1.01(\mathrm{t}, J=7.5 \mathrm{~Hz}, 3 \mathrm{H}), 1.25(\mathrm{~m}, 1 \mathrm{H}), 1.63-$ $1,75(\mathrm{~m}, 2 \mathrm{H}), 1.84\left(\mathrm{dt}, J_{1}=8.7 \mathrm{~Hz}, J_{2}=4.9 \mathrm{~Hz}, 1 \mathrm{H}\right), 3.11\left(\mathrm{dt}, J_{1}=8.1 \mathrm{~Hz}, J_{2}=6.3 \mathrm{~Hz}, 1 \mathrm{H}\right)$, 7.04-7.10 (m, 2H), $7.19(\mathrm{~m}, 1 \mathrm{H}), 7.23-7.32(\mathrm{~m}, 2 \mathrm{H}) .{ }^{13} \mathrm{C}-\mathrm{NMR}\left(75 \mathrm{MHz}, \mathrm{CDCl}_{3}\right) \delta 10.1$ $\left(\mathrm{CH}_{3}\right), 13.1\left(\mathrm{CH}_{2}\right), 21.2(\mathrm{CH}), 29.3(\mathrm{CH}), 30.2\left(\mathrm{CH}_{2}\right), 77.1(\mathrm{CH}), 125.6\left(\mathrm{CH}_{2}\right), 125.8(2 \mathrm{CH})$, 128.3 (2CH), 142.4 (C). IR (neat) vmax 3365, 3065, 3025, 2965, 2925, 2875, 1605, 1500, 1465 , 1095, 1030, 970, 750, 695, $545 \mathrm{~cm}-1$ HPLC (Chiralcel OD, hexane:isopropanol $=90: 10,1$ $\mathrm{mL} / \mathrm{min}, \lambda=220 \mathrm{~nm}) \mathrm{tR}=6.5 \mathrm{~min}$ for enantiomer $(\mathrm{S})-1-(1 \mathrm{~S}, 2 \mathrm{~S}), \mathrm{tR}=17.3 \mathrm{~min}$ for enantiomer (R)-1-(1R,2R). Configuration was assigned by comparing the 1H- and 13C-NMR spectra with literature data ${ }^{14,16 a}$ and the known absolute configuration of the corresponding allylic alcohol. ${ }^{18 a}$

(R)-1-((1R,2R)-2-(2-methoxyphenyl)cyclopropyl)propan-1-ol (3f). This compound was obtained from $(E)$-2-methoxycinnamaldehyde $(84 \mathrm{mg}, 0.5 \mathrm{mmol})$ and $\mathrm{CH}_{2} \mathrm{I}_{2}(80 \mu \mathrm{L}, 1$ $\mathrm{mmol}$ ), and purified by flash chromatography (ethyl acetate/hexane $=1 / 10)$. Colorless oil. $[\alpha]_{\mathrm{D}}{ }^{20}$ -23.4 (c 1.6, $\left.\mathrm{CHCl}_{3}\right) .{ }^{1} \mathrm{H}-\mathrm{NMR}\left(300 \mathrm{MHz}, \mathrm{CDCl}_{3}\right) \delta 0.91-0.97(\mathrm{~m}, 2 \mathrm{H}), 1.01(\mathrm{t}, J=7.5 \mathrm{~Hz}$, $3 \mathrm{H}), 1.20(\mathrm{~m}, 1 \mathrm{H}), 1.52-1.78(\mathrm{~m}, 2 \mathrm{H}), 1.83(\mathrm{~s}, 1 \mathrm{H}), 2.10(\mathrm{~m}, 1 \mathrm{H}), 3.18\left(\mathrm{td}, J_{1}=7.6 \mathrm{~Hz}, J_{2}=\right.$ $5.0 \mathrm{~Hz}, 1 \mathrm{H}), 3.86(\mathrm{~s}, 3 \mathrm{H}), 6.80-6.92(\mathrm{~m}, 3 \mathrm{H}), 7.18(\mathrm{~m}, 1 \mathrm{H}) .{ }^{13} \mathrm{C}-\mathrm{NMR}\left(75 \mathrm{MHz}, \mathrm{CDCl}_{3}\right) \delta 10.0$ $\left(\mathrm{CH}_{3}\right), 11.5\left(\mathrm{CH}_{2}\right), 15.1(\mathrm{CH}), 27.7(\mathrm{CH}), 29.4\left(\mathrm{CH}_{2}\right), 55.3\left(\mathrm{CH}_{3}\right), 76.9(\mathrm{CH}), 110.0(\mathrm{CH}), 120.4$ $(\mathrm{CH}), 125.6(\mathrm{CH}), 126.6(\mathrm{CH}), 130.4(\mathrm{C}), 158.0(\mathrm{C})$. IR (neat) vmax 3370, 3070, 2995, 2960, 2935, 2875, 2835, 1600, 1585, 1495, 1460, 1435, 1240, 1115, 1030, $750 \mathrm{~cm}^{-1} \mathrm{HRMS}$ calcd for $\mathrm{C}_{13} \mathrm{H}_{18} \mathrm{O}_{2}+\mathrm{Na}^{+}$, 229.1199; found, 229.1191. HPLC (Chiralpak AS-H, hexane:isopropanol = 99:01, $1 \mathrm{~mL} / \mathrm{min}, \lambda=220 \mathrm{~nm}) \mathrm{t}_{\mathrm{R}}=17.2 \mathrm{~min}$ for enantiomer $(S)-1-(1 S, 2 S), \mathrm{t}_{\mathrm{R}}=19.1 \mathrm{~min}$ for enantiomer $(R)-1-(1 R, 2 R)$. 


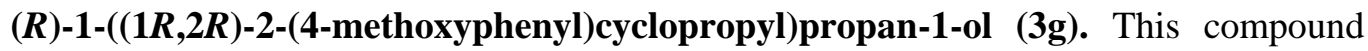
was obtained from $(E)$-4-methoxycinnamaldehyde $(83 \mathrm{mg}, 0.5 \mathrm{mmol})$ and $\mathrm{CH}_{2} \mathrm{I}_{2}(80 \mu \mathrm{L}, 1$ $\mathrm{mmol}$ ), and purified by flash chromatography (ethyl acetate/hexane $=1 / 10-1 / 4)$. Colorless oil. $[\alpha]_{\mathrm{D}}{ }^{20}-52.5\left(c 0.6, \mathrm{CHCl}_{3}\right) .{ }^{1} \mathrm{H}-\mathrm{NMR}\left(300 \mathrm{MHz}, \mathrm{CDCl}_{3}\right) \delta 0.82-0.96(\mathrm{~m}, 2 \mathrm{H}), 1.00(\mathrm{t}, J=7.5$ $\mathrm{Hz}, 3 \mathrm{H}), 1.17(\mathrm{~m}, 1 \mathrm{H}), 1.60-1.74(\mathrm{~m}, 3 \mathrm{H}), 1.78\left(\mathrm{dt}, J_{l}=9.1 \mathrm{~Hz}, J_{2}=5.0 \mathrm{~Hz}, 1 \mathrm{H}\right), 3.06\left(\mathrm{dt}, J_{l}=\right.$ $\left.8.1 \mathrm{~Hz}, J_{2}=6.3 \mathrm{~Hz}, 1 \mathrm{H}\right), 3.78(\mathrm{~s}, 3 \mathrm{H}), 6.82\left(\mathrm{~d}, J_{l}=8.8 \mathrm{~Hz}, 2 \mathrm{H}\right), 7.00\left(\mathrm{~d}, J_{l}=8.6 \mathrm{~Hz}, 2 \mathrm{H}\right),{ }^{13} \mathrm{C}-$ NMR $\left(75 \mathrm{MHz}, \mathrm{CDCl}_{3}\right) \delta 10.1\left(\mathrm{CH}_{3}\right), 12.6\left(\mathrm{CH}_{2}\right), 20.4(\mathrm{CH}), 28.8(\mathrm{CH}), 30.2\left(\mathrm{CH}_{2}\right), 55.3$ $\left(\mathrm{CH}_{3}\right), 77.2(\mathrm{CH}), 113.8(2 \mathrm{CH}), 126.9(2 \mathrm{CH}), 134.3(\mathrm{C}), 157.7(\mathrm{C})$. IR (neat) vmax 3380, 3070, 3000, 2960, 2930, 2875, 2835, 1615, 1580, 1515, 1460, 1295, 1245, 1180, 1035, 970, 825, 805, $550 \mathrm{~cm}^{-1 .}$ HRMS calcd for $\mathrm{C}_{13} \mathrm{H}_{18} \mathrm{O}_{2}+\mathrm{Na}^{+}, 229.1199$; found, 229.1193. HPLC (Chiralpak AS$\mathrm{H}$, hexane:isopropanol $=90: 10,1 \mathrm{~mL} / \mathrm{min}, \lambda=220 \mathrm{~nm}) \mathrm{t}_{\mathrm{R}}=7.0 \mathrm{~min}$ for enantiomer $(R)-1$ $(1 R, 2 R), \mathrm{t}_{\mathrm{R}}=8.1 \mathrm{~min}$ for enantiomer $(S)-1-(1 S, 2 S)$.

(R)-1-((1R,2R)-2-(2-furyl)cyclopropyl)propan-1-ol (3h). This compound was obtained from (E)-3-(2-furyl)acrylaldehyde $(63.0 \mathrm{mg}, 0.5 \mathrm{mmol})$ and $\mathrm{CH}_{2} \mathrm{I}_{2}(80 \mu \mathrm{L}, 1 \mathrm{mmol})$, and purified by flash chromatography (ethyl acetate/hexane $=1 / 10$ ). Colorless oil. $[\alpha]_{\mathrm{D}}{ }^{20}-79.5$ (c 1.0, $\left.\mathrm{CHCl}_{3}\right) .{ }^{1} \mathrm{H}-\mathrm{NMR}\left(300 \mathrm{MHz}, \mathrm{CDCl}_{3}\right) \delta 0.87-1.05(\mathrm{~m}, 2 \mathrm{H}), 1.01(\mathrm{t}, J=7.5 \mathrm{~Hz}, 3 \mathrm{H})$, $1.31(\mathrm{~m}, 1 \mathrm{H}), 1.59-1.73(\mathrm{~m}, 3 \mathrm{H}), 1.83\left(\mathrm{dt}, J_{1}=9.2 \mathrm{~Hz}, J_{2}=4.9 \mathrm{~Hz}, 1 \mathrm{H}\right), 3.09(\mathrm{q}, J=6.8 \mathrm{~Hz}$, $1 \mathrm{H}), 5.95(\mathrm{~d} J=3.2 \mathrm{~Hz}, 1 \mathrm{H}), 6.26\left(\mathrm{dd}, J_{l}=3.2 \mathrm{~Hz}, J_{2}=1.9 \mathrm{~Hz}, 1 \mathrm{H}\right), 7.24(\mathrm{~d}, J=1.9 \mathrm{~Hz}, 1 \mathrm{H})$. ${ }^{13} \mathrm{C}-\mathrm{NMR}\left(75 \mathrm{MHz}, \mathrm{CDCl}_{3}\right) \delta 9.9\left(\mathrm{CH}_{3}\right), 10.7\left(\mathrm{CH}_{2}\right), 14.3(\mathrm{CH}), 26.5(\mathrm{CH}), 30.2\left(\mathrm{CH}_{2}\right), 76.1$ $(\mathrm{CH}), 103.6(\mathrm{CH}), 110.2(\mathrm{CH}), 140.5(\mathrm{CH}), 156.0(\mathrm{C})$. IR (neat) vmax 3360, 3010, 2965, 2925, 2880, 1600, 1510, 1175, 1150, 1010, 965, 915, 790, 725, $595 \mathrm{~cm}^{-1}$. HRMS calcd for $\mathrm{C}_{10} \mathrm{H}_{14} \mathrm{O}+$ $\mathrm{Na}^{+}, 189.0886$; found, 189.0894. HPLC (Chiralpak AD-H, hexane:isopropanol $=98: 02,1$ $\mathrm{mL} / \mathrm{min}, \lambda=220 \mathrm{~nm}) \mathrm{t}_{\mathrm{R}}=16.3 \mathrm{~min}$ for enantiomer $(R)-1-(1 R, 2 R), \mathrm{t}_{\mathrm{R}}=18.7$ min for enantiomer $(S)-1-(1 S, 2 S)$.

$(R)$-1-((1R,3R)-3-methyl-2,2-diphenylcyclopropyl)propan-1-ol (4d). This compound was obtained from $\beta$-phenylcinnamaldehyde $(104 \mathrm{mg}, 0.5 \mathrm{mmol})$ and $\mathrm{CH}_{3} \mathrm{CHIZnOCH}_{2} \mathrm{CF}_{3}(1.1$ mmol, from $\mathrm{Et}_{2} \mathrm{Zn}(1.1 \mathrm{~mL}, 1.1 \mathrm{mmol}), \mathrm{CF}_{3} \mathrm{CH}_{2} \mathrm{OH}(80 \mu \mathrm{L}, 1.1 \mathrm{mmol})$ and $\mathrm{CH}_{3} \mathrm{CHI}_{2}(310 \mathrm{mg}$, $1.1 \mathrm{mmol})$ ), and purified by flash chromatography $\left(\mathrm{Et}_{2} \mathrm{O} / \mathrm{CH}_{2} \mathrm{Cl}_{2} /\right.$ hexane $\left.=1 / 3 / 16\right)$. Colorless oil. $[\alpha]_{\mathrm{D}}{ }^{20}-231\left(c 0.4, \mathrm{CHCl}_{3}\right) .{ }^{1} \mathrm{H}-\mathrm{NMR}\left(400 \mathrm{MHz}, \mathrm{CDCl}_{3}\right) \delta 0.91(\mathrm{t}, J=7.4 \mathrm{~Hz}, 3 \mathrm{H}), 0.94(\mathrm{~d}$, $J=6.5 \mathrm{~Hz}, 3 \mathrm{H}), 1.21(\mathrm{br} \mathrm{s}, 1 \mathrm{H}), 1.51\left(\mathrm{dd}, J_{1}=8.3 \mathrm{~Hz}, J_{2}=5.7 \mathrm{~Hz}, 1 \mathrm{H}\right), 1.60(\mathrm{~m}, 1 \mathrm{H}), 1.73(\mathrm{~m}$, $1 \mathrm{H}), 1.90\left(\mathrm{dq}, J_{2}=5.7 \mathrm{~Hz}, J_{2}=6.2 \mathrm{~Hz}, 1 \mathrm{H}\right), 2.89\left(\mathrm{td}, J_{1}=8.0 \mathrm{~Hz}, J_{2}=3.6 \mathrm{~Hz}, 1 \mathrm{H}\right), 7.11-7.19$ $(\mathrm{m}, 2 \mathrm{H}), 7.20-7.29(\mathrm{~m}, 8 \mathrm{H}) .{ }^{13} \mathrm{C}-\mathrm{NMR}\left(100 \mathrm{MHz}, \mathrm{CDCl}_{3}\right) \delta 9.9\left(\mathrm{CH}_{3}\right), 15.5\left(\mathrm{CH}_{3}\right), 19.9(\mathrm{CH})$, $29.9\left(\mathrm{CH}_{2}\right), 37.0(\mathrm{CH}), 40.8(\mathrm{C}), 73.2(\mathrm{CH}), 126.1(\mathrm{CH}), 126.1(\mathrm{CH}), 128.2(2 \mathrm{CH}), 128.2$ $(2 \mathrm{CH}), 129.6(2 \mathrm{CH}), 130.1(2 \mathrm{CH}), 142.8(\mathrm{C}), 142.9$ (C). IR (neat) vmax 3342, 3060, 3025, $2960,2925,2855,1600,1495,1445,960,770,750,700,650 \mathrm{~cm}^{-1}$. HRMS calcd for $\mathrm{C}_{19} \mathrm{H}_{22} \mathrm{O}+$ $\mathrm{Na}^{+}, 289,1563$; found, 289,1550. HPLC (Chiralpak OD, hexane:isopropanol $=98: 02,1 \mathrm{~mL} / \mathrm{min}$, $\lambda=220 \mathrm{~nm}) \mathrm{t}_{\mathrm{R}}=10.0 \mathrm{~min}$ for enantiomer $(R)-1-(1 R, 3 R), \mathrm{t}_{\mathrm{R}}=12.2$ min for enantiomer $(S)-1-$ $(1 S, 3 S)$.

\section{Typical procedure for enantioselective one-pot synthesis of (cyclopropyl)(phenyl)methanols from $\alpha, \beta$-unsaturated aldehydes, diethylzinc and triphenylboroxin}

To a suspension of triphenylboroxin $(106.3 \mathrm{mg}, 0.3 \mathrm{mmol})$ in anhydrous toluene $(0.5$ $\mathrm{mL}$ ) under argon atmosphere was added dropwise a $1.1 \mathrm{M}$ solution of $\mathrm{Et}_{2} \mathrm{Zn}$ in toluene $(1.1 \mathrm{~mL}$, $1.2 \mathrm{mmol})$. The resulting mixture was heated at $60^{\circ} \mathrm{C}$ in a pre-heated bath for $30 \mathrm{~min}$ to give a clear solution. Once this solution was cooled to room temperature, a solution of the ligand 1 (18 
$\mathrm{mg}, 0.05 \mathrm{mmol})$ in toluene $(0.5 \mathrm{~mL})$ was added. The resulting mixture was then cooled to $0^{\circ} \mathrm{C}$ in an ice bath and after $15 \mathrm{~min}$ of stirring at that temperature, the aldehyde $(0.5 \mathrm{mmol})$ was added. After $60 \mathrm{~min}, \mathrm{Et}_{2} \mathrm{Zn}(1 \mathrm{~mL}, 1.1 \mathrm{mmol})$ was added to the reaction mixture at $0^{\circ} \mathrm{C}$. Next, dropwise addition of $\mathrm{CF}_{3} \mathrm{CH}_{2} \mathrm{OH}(80 \mu \mathrm{L}, 1.1 \mathrm{mmol})$ was performed over $20 \mathrm{~min}$ and after another $20 \mathrm{~min}$, $\mathrm{CH}_{2} \mathrm{I}_{2}(88 \mu \mathrm{L}, 1.1 \mathrm{mmol})$ was added. Then, the reaction mixture was stirred at room temperature with light exclusion for $24 \mathrm{~h}$. Finally, the reaction mixture was quenched with saturated aqueous $\mathrm{NH}_{4} \mathrm{Cl}$, extracted with $\mathrm{CH}_{2} \mathrm{Cl}_{2}(3 \times 15 \mathrm{~mL})$, dried over $\mathrm{MgSO}_{4}$, filtered off, and the solvents were evaporated. Purification by silica gel column chromatography with different mixtures of ethyl acetate/hexane gave the pure alcohols. Enantiomeric excesses were determined by chiral HPLC.

$(S)-((1 R, 2 S)$-1-methyl-2-phenylcyclopropyl)(phenyl)methanol (6a). This compound was obtained from $(E)-\alpha$-methylcinnamaldehyde $(71 \mu \mathrm{L}, 0.5 \mathrm{mmol})$ and purified by flash chromatography (ethyl acetate/hexane $=1 / 30)$. Colorless oil. $[\alpha]_{\mathrm{D}}{ }^{20}-26.6\left(c 0.3, \mathrm{CHCl}_{3}\right) .{ }^{1} \mathrm{H}-$ $\operatorname{NMR}\left(400 \mathrm{MHz}, \mathrm{CDCl}_{3}\right) \delta 0.66(\mathrm{~s}, 3 \mathrm{H}), 0.96\left(\mathrm{dd}, J_{l}=5.9 \mathrm{~Hz}, J_{2}=5.0 \mathrm{~Hz}, 1 \mathrm{H}\right), 1.18\left(\mathrm{dd}, J_{l}=\right.$ $\left.8.9 \mathrm{~Hz}, J_{2}=4.9 \mathrm{~Hz}, 1 \mathrm{H}\right), 1.94(\mathrm{br} \mathrm{s}, 1 \mathrm{H}, \mathrm{OH}), 2.38\left(\mathrm{dd}, J_{1}=8.9 \mathrm{~Hz}, J_{2}=6.0 \mathrm{~Hz}, 1 \mathrm{H}\right), 4.38(\mathrm{~s}$, 1H), $7.02-7.11(\mathrm{~m}, 2 \mathrm{H}), 7.11-7.18(\mathrm{~m}, 1 \mathrm{H}), 7.19-7.25(\mathrm{~m}, 2 \mathrm{H}), 7.28-7.34(\mathrm{~m}, 1 \mathrm{H}), 7.36$ $7.43(\mathrm{~m}, 2 \mathrm{H}), 7.45-7.53(\mathrm{~m}, 2 \mathrm{H}) .{ }^{13} \mathrm{C}-\mathrm{NMR}\left(100 \mathrm{MHz}, \mathrm{CDCl}_{3}\right) \delta 13.8\left(\mathrm{CH}_{3}\right), 15.9\left(\mathrm{CH}_{2}\right), 26.4$ $(\mathrm{CH}), 28.7(\mathrm{C}), 80.7(\mathrm{CH}), 125.9(\mathrm{CH}), 126.3(2 \mathrm{CH}), 127.4(\mathrm{CH}), 127.9(2 \mathrm{CH}), 128.1(2 \mathrm{CH})$, $129.1(2 \mathrm{CH}), 138.5(\mathrm{C}), 142.4$ (C). IR (neat) vmax 3390, 3060, 3030, 2960, 2920, 2850, 1605, 1495, 1450, 1025, 775, 740, 725, 695, $580 \mathrm{~cm}^{-1}$. HRMS calcd for $\mathrm{C}_{17} \mathrm{H}_{18} \mathrm{O}+\mathrm{Na}^{+}, 261.1250$; found, 261.1254. HPLC (Chiralcel OD, hexane:isopropanol $=90: 10,1 \mathrm{~mL} / \mathrm{min}, \lambda=220 \mathrm{~nm}$ ) $\mathrm{t}_{\mathrm{R}}$ $=9.7$ min for enantiomer $(S)-(1 R, 2 S), \mathrm{t}_{\mathrm{R}}=11.7 \mathrm{~min}$ for enantiomer $(R)-(1 S, 2 R)$.

(S)-((1S,2R)-1-methyl-2-phenylcyclopropyl)(phenyl)methanol (7a).This compound was obtained from $(E)$ - $\alpha$-methylcinnamaldehyde $(71 \mu \mathrm{L}, 0.5 \mathrm{mmol})$ and purified by flash chromatography (ethyl acetate/hexane $=1 / 30)$. Colorless oil. $[\alpha]_{\mathrm{D}}{ }^{20}+6.6\left(c 0.3, \mathrm{Et}_{2} \mathrm{O}\right) .{ }^{1} \mathrm{H}-\mathrm{NMR}$ $\left(400 \mathrm{MHz}, \mathrm{CDCl}_{3}\right) \delta 0.67(\mathrm{~s}, 3 \mathrm{H}), 0.89(\mathrm{t}, J=5.6 \mathrm{~Hz}, 1 \mathrm{H}), 1.25\left(\mathrm{dd}, J_{1}=8.8 \mathrm{~Hz}, J_{2}=5.1 \mathrm{~Hz}\right.$, $1 \mathrm{H}), 1.91(\mathrm{~d}, J=3.2 \mathrm{~Hz}, 1 \mathrm{H}, \mathrm{OH}), 2.35\left(\mathrm{dd}, J_{l}=9.0 \mathrm{~Hz}, J_{2}=6.0 \mathrm{~Hz}, 1 \mathrm{H}\right), 4.42(\mathrm{~d}, J=2.9 \mathrm{~Hz}$, $1 \mathrm{H}), 7.15-7.22(\mathrm{~m}, 3 \mathrm{H}), 7.24-7.34(\mathrm{~m}, 3 \mathrm{H}), 7.35-7.41(\mathrm{~m}, 2 \mathrm{H}), 7.42-7.47(\mathrm{~m}, 2 \mathrm{H}),{ }^{13} \mathrm{C}-$ NMR $\left(100 \mathrm{MHz}, \mathrm{CDCl}_{3}\right) \delta 14.1\left(\mathrm{CH}_{3}\right), 15.2\left(\mathrm{CH}_{2}\right), 27.0(\mathrm{CH}), 28.6(\mathrm{C}), 80.1(\mathrm{CH}), 125.9(\mathrm{CH})$, $126.4(2 \mathrm{CH}), 127.5(\mathrm{CH}), 128.0(2 \mathrm{CH}), 128.2(2 \mathrm{CH}), 129.1(2 \mathrm{CH}), 139.0(\mathrm{C}), 142.5(\mathrm{C}) . \mathrm{IR}$ (neat) vmax 3410, 3060, 3030, 2920, 2850, 1605, 1495, 1450, 1025, 775, 740, 725, $700 \mathrm{~cm}^{-1}$. HRMS calcd for $\mathrm{C}_{17} \mathrm{H}_{18} \mathrm{O}+\mathrm{Na}^{+}, 261.1250$; found, 261.1265. HPLC (Chiralpak AS-H, hexane:isopropanol $=98: 02,1 \mathrm{~mL} / \mathrm{min}, \lambda=220 \mathrm{~nm}) \mathrm{t}_{\mathrm{R}}=9.7 \mathrm{~min}$ for enantiomer $(R)-(1 R, 2 S), \mathrm{t}_{\mathrm{R}}$ $=11.2 \mathrm{~min}$ for enantiomer $(S)-((1 S, 2 R)$.

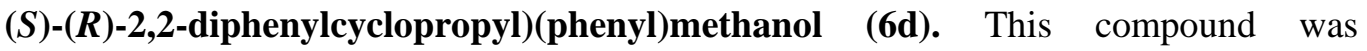
obtained from $\beta$-phenylcinnamaldehyde $(104 \mathrm{mg}, 0.5 \mathrm{mmol})$ and purified by flash chromatography (ethyl acetate/hexane $=1 / 20)$. White solid. Mp 104-106 ${ }^{\circ} \mathrm{C} .[\alpha]_{\mathrm{D}}{ }^{20}-34.4(c 1.2$, $\left.\mathrm{CHCl}_{3}\right) .{ }^{1} \mathrm{H}-\mathrm{NMR}\left(400 \mathrm{MHz}, \mathrm{CDCl}_{3}\right) \delta 1.42\left(\mathrm{dd}, J_{l}=8.8 \mathrm{~Hz}, J_{2}=5.0 \mathrm{~Hz}, 1 \mathrm{H}\right), 1.85(\mathrm{t}, J=5.5$ $\mathrm{Hz}, 1 \mathrm{H}), 1.92(\mathrm{br} \mathrm{s}, 1 \mathrm{H}, \mathrm{OH}), 2.28\left(\mathrm{td}, J_{l}=8.8 \mathrm{~Hz}, J_{2}=5.9 \mathrm{~Hz}, 1 \mathrm{H}\right), 3.97(\mathrm{~d}, J=8.8 \mathrm{~Hz}, 1 \mathrm{H})$, $7.10-7.31(\mathrm{~m}, 12 \mathrm{H}), 7.31-7.42(\mathrm{~m}, 3 \mathrm{H}) .{ }^{13} \mathrm{C}-\mathrm{NMR}\left(100 \mathrm{MHz}, \mathrm{CDCl}_{3}\right) \delta 17.9\left(\mathrm{CH}_{2}\right), 32.5$ $(\mathrm{CH}), 35.9(\mathrm{C}), 74.7(\mathrm{CH}), 126.0(\mathrm{CH}), 126.6(\mathrm{CH}), 126.8(2 \mathrm{CH}), 127.8(\mathrm{CH}), 128.0(2 \mathrm{CH})$, $128.1(2 \mathrm{CH}), 128.2(2 \mathrm{CH}), 128.4(2 \mathrm{CH}), 130.2(2 \mathrm{CH}), 140.5(\mathrm{C}), 143.2(\mathrm{C}), 146.1(\mathrm{C}) . \mathrm{IR}$ (neat) $v \max 3335,3060,3025,2920,2855,1600,1495,1445,1150,1035,1020,760,750,695$, $640,625,585,550,535 \mathrm{~cm}^{-1}$. HRMS calcd for $\mathrm{C}_{22} \mathrm{H}_{20} \mathrm{O}+\mathrm{Na}^{+}, 323.1406$; found, 323.1389 . HPLC (Chiralcel OD, hexane:isopropanol $=98: 02,1 \mathrm{~mL} / \mathrm{min}, \lambda=220 \mathrm{~nm}$ ) $\mathrm{t}_{\mathrm{R}}=21.2 \mathrm{~min}$ for enantiomer $(R)-(S), \mathrm{t}_{\mathrm{R}}=24.0$ min for enantiomer $(S)-(R)$. 
(S)-phenyl((1R,2R)-2-phenylcyclopropyl)methanol (6e). This compound was obtained from $(E)$-cinnamaldehyde $(63 \mu \mathrm{L}, 0.5 \mathrm{mmol})$ and purified by flash chromatography (ethyl acetate/hexane $=1 / 15)$. White solid. Mp 57-58 ${ }^{\circ} \mathrm{C} .[\alpha]_{\mathrm{D}}{ }^{20}-61.2\left(\mathrm{c} 0.6, \mathrm{CHCl}_{3}\right) .{ }^{1} \mathrm{H}-\mathrm{NMR}$ $\left(400 \mathrm{MHz}, \mathrm{CDCl}_{3}\right) \delta 1.07\left(\mathrm{dt}, J_{l}=8.4 \mathrm{~Hz}, J_{2}=5.2 \mathrm{~Hz}, 1 \mathrm{H}\right), 1.20\left(\mathrm{dt}, J_{l}=8.9 \mathrm{~Hz}, J_{2}=5.3 \mathrm{~Hz}\right.$, 1H), $1.51-1.60(\mathrm{~m}, 1 \mathrm{H}), 1.86-2.14(\mathrm{~m}, 2 \mathrm{H}), 4.38(\mathrm{~d}, J=7.4 \mathrm{~Hz}, 1 \mathrm{H}), 6.98-7.07(\mathrm{~m}, 2 \mathrm{H}), 7.10$ - $7.18(\mathrm{~m}, 1 \mathrm{H}), 7.20-7.26(\mathrm{~m}, 2 \mathrm{H}), 7.27-7.33(\mathrm{~m}, 1 \mathrm{H}), 7.33-7.40(\mathrm{~m}, 2 \mathrm{H}), 7.41-7.50(\mathrm{~m}$, 2H). ${ }^{13} \mathrm{C}-\mathrm{NMR}\left(100 \mathrm{MHz}, \mathrm{CDCl}_{3}\right) \delta 13.6\left(\mathrm{CH}_{2}\right), 21.0(\mathrm{CH}), 30.0(\mathrm{CH}), 76.8(\mathrm{CH}), 125.7(\mathrm{CH})$, $126.0(2 \mathrm{CH}), 126.0(2 \mathrm{CH}), 127.7(\mathrm{CH}), 128.3(2 \mathrm{CH}), 128.5(2 \mathrm{CH}), 142.0(\mathrm{C}), 143.5$ (C). iError! Marcador no definido. IR (neat) vmax 3230, 3025, 1600, 1500, 1455, 1090, 1055, 1030, 1020, 765, 755, 695, 635, 550, $535 \mathrm{~cm}^{-1}$. HRMS calcd for $\mathrm{C}_{16} \mathrm{H}_{16} \mathrm{O}+\mathrm{Na}^{+}, 247.1093$; found, 247.1075. HPLC (Chiralpak AS-H, hexane:isopropanol $=99: 01,1 \mathrm{~mL} / \mathrm{min}, \lambda=220 \mathrm{~nm}$ ) $\mathrm{t}_{\mathrm{R}}=26.1 \mathrm{~min}$ for enantiomer $(R)-(1 S, 2 S), \mathrm{t}_{\mathrm{R}}=27.6 \mathrm{~min}$ for enantiomer $(S)-(1 R, 2 R)$. Configuration was assigned by comparing the sign of optical rotation of the derived ketocyclopropane (see preparation of $\mathbf{8 e}$ from $\mathbf{6 e}$ below).

(S)-phenyl((1S,2S)-2-phenylcyclopropyl)methanol (7e). This compound was obtained from $(E)$-cinnamaldehyde $(63 \mu \mathrm{L}, 0.5 \mathrm{mmol})$ and purified by flash chromatography (ethyl acetate/hexane $=1 / 15)$. Colorless oil. $[\alpha]_{\mathrm{D}}{ }^{20}-13.1\left(\mathrm{c} 0.3, \mathrm{CHCl}_{3}\right) .{ }^{1} \mathrm{H}-\mathrm{NMR}\left(400 \mathrm{MHz}, \mathrm{CDCl}_{3}\right)$ $\delta 0.99\left(\mathrm{dt}, J_{l}=8.7 \mathrm{~Hz}, J_{2}=5.2 \mathrm{~Hz}, 1 \mathrm{H}\right), 1.09\left(\mathrm{dt}, J_{l}=8.9 \mathrm{~Hz}, J_{2}=5.4 \mathrm{~Hz}, 1 \mathrm{H}\right), 1.52-1.62(\mathrm{~m}$, $1 \mathrm{H}), 2.00(\mathrm{br} \mathrm{s}, 1 \mathrm{H}, \mathrm{OH}), 2.10\left(\mathrm{dt}, J_{l}=9.4 \mathrm{~Hz}, J_{2}=4.7 \mathrm{~Hz}, 1 \mathrm{H}\right), 4.32(\mathrm{~d}, J=7.8 \mathrm{~Hz}, 1 \mathrm{H}), 7.04-$ $7.13(\mathrm{~m}, 2 \mathrm{H}), 7.13-7.21(\mathrm{~m}, 1 \mathrm{H}), 7.23-7.34(\mathrm{~m}, 3 \mathrm{H}), 7.35-7.41(\mathrm{~m}, 2 \mathrm{H}), 7.43-7.48(\mathrm{~m}, 2 \mathrm{H})$. ${ }^{13} \mathrm{C}-\mathrm{NMR}\left(100 \mathrm{MHz}, \mathrm{CDCl}_{3}\right) \delta 13.5\left(\mathrm{CH}_{2}\right), 21.9(\mathrm{CH}), 30.7(\mathrm{CH}), 77.5(\mathrm{CH}), 125.7(\mathrm{CH})$, $125.9(2 \mathrm{CH}), 126.1(2 \mathrm{CH}), 127.7(\mathrm{CH}), 128.4(2 \mathrm{CH}), 128.5(2 \mathrm{CH}), 142.3(\mathrm{C}), 143.4(\mathrm{C}) . \mathrm{IR}$ (neat) vmax 3355, 3060, 2920, 2850, 1605, 1460, 1455, 1020, 760, 740, 700, $550 \mathrm{~cm}^{-1}$. HRMS calcd for $\mathrm{C}_{16} \mathrm{H}_{16} \mathrm{O}+\mathrm{Na}^{+}, 247.1093$; found, 247.1098. HPLC (Chiralpak AS-H, hexane:isopropanol $=99: 01,1 \mathrm{~mL} / \mathrm{min}, \lambda=220 \mathrm{~nm}) \mathrm{t}_{\mathrm{R}}=23.8 \mathrm{~min}$ for enantiomer $(R)-(1 R, 2 R)$, $t_{\mathrm{R}}=26.1$ min for enantiomer $(S)-(1 S, 2 S)$.

(S)-((1R,2R)-2-(2-furyl)cyclopropyl)(phenyl)methanol (6h). This compound was obtained from (E)-3-(2-furyl)acrylaldehyde $(63.0 \mathrm{mg}, 0.5 \mathrm{mmol})$ and purified by flash chromatography (ethyl acetate/hexane $=1 / 15$ ). The product was obtained as an inseparable mixture of diastereoisomers $\mathbf{6 h}$ and $\mathbf{7 h}$ (enriched in $\mathbf{6 h}$ ). Yellow oil. ${ }^{1} \mathrm{H}-\mathrm{NMR}(400 \mathrm{MHz}$, $\left.\mathrm{CDCl}_{3}\right) \delta 1.02-1.28(\mathrm{~m}, 2 \mathrm{H}), 1.58-1.72(\mathrm{~m}, 1 \mathrm{H}), 1.94(\mathrm{br} \mathrm{s}, 1 \mathrm{H}, \mathrm{OH}), 1.91-2.05(\mathrm{~m}, 2 \mathrm{H})$, $4.42(\mathrm{~d}, J=7.0 \mathrm{~Hz}, 1 \mathrm{H}), 5.92\left(\mathrm{dt}, J_{1}=3.2 \mathrm{~Hz}, J_{2}=0.8 \mathrm{~Hz}, 1 \mathrm{H}\right), 6.24\left(\mathrm{dd}, J_{l}=3.2 \mathrm{~Hz}, J_{2}=1.9\right.$ $\mathrm{Hz}, 1 \mathrm{H}), 7.21\left(\mathrm{dd}, J_{l}=1.9 \mathrm{~Hz}, J_{2}=0.9 \mathrm{~Hz}, 1 \mathrm{H}\right), 7.27-7.33(\mathrm{~m}, 1 \mathrm{H}), 7.34-7.40(\mathrm{~m}, 2 \mathrm{H}), 7.41-$ $7.49(\mathrm{~m}, 2 \mathrm{H}) .{ }^{13} \mathrm{C}-\mathrm{NMR}\left(100 \mathrm{MHz}, \mathrm{CDCl}_{3}\right) \delta 11.3\left(\mathrm{CH}_{2}\right), 14.1(\mathrm{CH}), 27.3(\mathrm{CH}), 75.7(\mathrm{CH})$, $103.8(\mathrm{CH}), 110.2(\mathrm{CH}), 126.0(2 \mathrm{CH}), 127.7(\mathrm{CH}), 128.5(2 \mathrm{CH}), 140.6(\mathrm{CH}), 143.2(\mathrm{C}), 155.6$ (C). IR (neat) vmax 3375, 3030, 2925, 2855, 1600, 1510, 1455, 1080, 1010, 730, 700, $600 \mathrm{~cm}^{-1}$. HRMS calcd for $\mathrm{C}_{14} \mathrm{H}_{14} \mathrm{O}_{2}+\mathrm{Na}^{+}, 237.0886$; found, 237.0881. HPLC (Chiralcel OD, hexane:isopropanol $=99: 01,1 \mathrm{~mL} / \mathrm{min}, \lambda=220 \mathrm{~nm}) \mathrm{t}_{\mathrm{R}}=57.1 \mathrm{~min}$ for enantiomer $(S)-(1 R, 2 R)$, $\mathrm{t}_{\mathrm{R}}=60.7$ min for enantiomer $(R)-(1 S, 2 S)$.

(S)-((1R,2R)-2-(2-furyl)cyclopropyl)(phenyl)methanol (minor diaster.) (7h). This compound was obtained from (E)-3-(2-furyl)acrylaldehyde $(63.0 \mathrm{mg}, 0.5 \mathrm{mmol})$ and purified by flash chromatography (ethyl acetate/hexane $=1 / 15$ ). An analytical amount of $\mathbf{7 h}$ could be obtained for characterisation purposes. Yellow oil. $[\alpha]_{\mathrm{D}}{ }^{20}-19.3\left(\mathrm{c} 0.1, \mathrm{CHCl}_{3}\right) .{ }^{1} \mathrm{H}-\mathrm{NMR}(400$ $\left.\mathrm{MHz} \mathrm{CDCl}_{3}\right) \delta 0.94-1.11(\mathrm{~m}, 2 \mathrm{H}), 1.60-1.71(\mathrm{~m}, 1 \mathrm{H}), 1.98(\mathrm{br} \mathrm{s}, 1 \mathrm{H}, \mathrm{OH}), 2.10\left(\mathrm{dt}, J_{1}=8.9\right.$ $\left.\mathrm{Hz}, J_{2}=5.0 \mathrm{~Hz}, 1 \mathrm{H}\right), 4.29(\mathrm{~d}, J=7.7 \mathrm{~Hz}, 1 \mathrm{H}), 5.98\left(\mathrm{dt}, J_{1}=3.2 \mathrm{~Hz}, J_{2}=0.8 \mathrm{~Hz}, 1 \mathrm{H}\right), 6.27(\mathrm{dd}$, $\left.J_{l}=3.2 \mathrm{~Hz}, J_{2}=1.9 \mathrm{~Hz}, 1 \mathrm{H}\right), 7.24\left(\mathrm{dd}, J_{1}=1.9 \mathrm{~Hz}, J_{2}=0.9 \mathrm{~Hz}, 1 \mathrm{H}\right), 7.28-7.33(\mathrm{~m}, 1 \mathrm{H}), 7.34-$ 
$7.40(\mathrm{~m}, 2 \mathrm{H}), 7.42-7.46(\mathrm{~m}, 2 \mathrm{H}) .{ }^{13} \mathrm{C}-\mathrm{NMR}\left(100 \mathrm{MHz}, \mathrm{CDCl}_{3}\right) \delta 11.1\left(\mathrm{CH}_{2}\right), 15.0(\mathrm{CH}), 28.0$ $(\mathrm{CH}), 76.8(\mathrm{CH}), 103.8(\mathrm{CH}), 110.3(\mathrm{CH}), 126.1(2 \mathrm{CH}), 127.8(\mathrm{CH}), 128.5(2 \mathrm{CH}), 140.6(\mathrm{CH})$, 143.1 (C), 155.7 (C). ¿Error! Marcador no definido. IR (neat) vmax 3395, 2925, 2855, 1600, $1455,1265,1080,1010,735,700,600 \mathrm{~cm}^{-1}$. HRMS calcd for $\mathrm{C}_{14} \mathrm{H}_{14} \mathrm{O}_{2}+\mathrm{Na}^{+}, 237.0886$; found, 237.0884. HPLC (Chiralcel OD, hexane:isopropanol $=99: 01,1 \mathrm{~mL} / \mathrm{min}, \lambda=220 \mathrm{~nm}$ ) $\mathrm{t}_{\mathrm{R}}=63.3$ $\min$ for enantiomer $(S)-(1 S, 2 S), \mathrm{t}_{\mathrm{R}}=90.2 \mathrm{~min}$ for enantiomer $(R)-(1 R, 2 R)$.

Configuration assignment of cyclopropane 6e: Synthesis of phenyl $((1 R, 2 R)-2-$ phenylcyclopropyl)methanone $8 \mathbf{e}$ from $6 \mathbf{e}$. To a solution of $6 \mathbf{e}(56 \mathrm{mg}, 0.25 \mathrm{mmol})$ in $\mathrm{CH}_{2} \mathrm{Cl}_{2}$ $(5 \mathrm{~mL})$ at room temperature was added carefully PCC ( $83 \mathrm{mg}, 0.38 \mathrm{mmol}, 1.5 \mathrm{eq})$. After $60 \mathrm{~min}$ stirring (TLC monitored), a $1.0 \mathrm{M}$ solution of $\mathrm{NaOH}(3 \mathrm{~mL})$ was added and the resulting mixture was extracted with $\mathrm{CH}_{2} \mathrm{Cl}_{2}(5 \times 15 \mathrm{~mL})$, dried over $\mathrm{MgSO}_{4}$, filtered off, and the solvents were evaporated. Purification by silica gel column chromatography with ethyl acetate/hexane $=1 / 75$ gave the pure ketone 8e. White solid. Mp $46-48^{\circ} \mathrm{C}$. $[\alpha]_{\mathrm{D}}{ }^{20}-288$ (c 0.2 , acetone), [lit. ${ }^{22}[\alpha]_{\mathrm{D}}{ }^{29}+351$, (c 0.549, acetone) for $\left.(1 S, 2 S)\right] .{ }^{1} \mathrm{H}-\mathrm{NMR}\left(400 \mathrm{MHz}, \mathrm{CDCl}_{3}\right) \delta 1.56$ $\left(\mathrm{ddd}, J_{1}=8.0 \mathrm{~Hz}, J_{2}=6.6 \mathrm{~Hz}, J_{3}=4.1 \mathrm{~Hz}, 1 \mathrm{H}\right), 1.93\left(\mathrm{ddd}, J_{1}=9.2 \mathrm{~Hz}, J_{2}=5.3 \mathrm{~Hz}, J_{3}=4.1 \mathrm{~Hz}\right.$, $1 \mathrm{H}), 2.71\left(\mathrm{ddd}, J_{1}=9.0 \mathrm{~Hz}, J_{2}=6.6 \mathrm{~Hz}, J_{3}=4.0 \mathrm{~Hz}, 1 \mathrm{H}\right), 2.91\left(\mathrm{ddd}, J_{1}=8.1 \mathrm{~Hz}, J_{2}=5.3 \mathrm{~Hz}, J_{3}\right.$ $=4.0 \mathrm{~Hz}, 1 \mathrm{H}), 7.15-7.21(\mathrm{~m}, 2 \mathrm{H}), 7.21-7.25(\mathrm{~m}, 1 \mathrm{H}), 7.28-7.34(\mathrm{~m}, 2 \mathrm{H}), 7.41-7.49(\mathrm{~m}$, 2H), 7.52 - $7.60(\mathrm{~m}, 1 \mathrm{H}), 7.96-8.02(\mathrm{~m}, 2 \mathrm{H}) .{ }^{13} \mathrm{C}-\mathrm{NMR}\left(100 \mathrm{MHz}, \mathrm{CDCl}_{3}\right) \delta 19.2,29.3,30.0$, 126.2 (2), 126.6, 128.1 (2), 128.6 (4), 132.9, 137.7, 140.5, 198.5. IR (neat) vmax 3060, 3025, $2920,2875,1680,1665,1595,1580,1450,1400,1205,980,750,730,695,685,565,525,500$

$\mathrm{cm}^{-1}$. Absolute configuration was assigned by comparing the sign of optical rotation with literature data. ${ }^{22}$

\section{Acknowledgments}

We acknowledge the financial support by the Spanish DGICYT (Project CTQ201128487). R. I. also thanks Junta de Castilla y León for a predoctoral fellowship

\section{Notes and references}

1 For review see: a) M. Lautens, W. Klute, W. Tam, Chem. Rev. 1996, 96, 49-92. b) R. C. Hartley, S. T. Caldwell, J. Chem. Soc., Perkin Trans. 1, 2000, 477-502. c) A. B. Charette, A. Beauchemin, Org. React. 2001, 58, 1-415. d) W. A. Donaldson, Tetrahedron 2001, 57, 85898627. e) J. Pietruszka, Chem. Rev. 2003, 103, 1051-1070. f) H. Lebel, J.-F. Marcoux, C. Molinaro, A. B. Charette, Chem. Rev. 2003, 103, 977-1050. g) L. A. Wessjohann, W. Brandt, T. Thiemann Chem. Rev. 2003, 103, 1625-1648. h) H.-U. Reissig, R. Zimmer, Chem. Rev. 2003, 103, 1151-1196. i) P. Garcia, D. D. Martin, A. B. Anton, N. M. Garrido, I. S. Marcos, P. Basabe, J. G. Urones, Mini Rev. Org. Chem. 2006, 3, 291-314. j) H. Pellissier, Tetrahedron 2008, 64, 7041-7095.Goering, B. K. Ph.D. Dissertation, Cornell University, 1995.

2 For recent examples: a) S. Hanessian, T. Focken, X. Mi, R. Oza, B. Chen, D. Ritson, R. Beaudegnies, J. Org. Chem. 2010, 75, 5601-5618. b) A. Robinson, V. K. Aggarwal, Angew. Chem. Int. Ed. 2010, 49, 6673-6675. c) J. B. Son, S. N. Kim, N. Y. Kim, M.-H. Hwang, W. Lee, D. H. Lee, Bull. Korean Chem. Soc. 2010, 31, No. 3. d) M. Bischop, V. Doum, A. C. M. Nordschild, J. Pietruszka, D. Sandkuhl, Synthesis 2010, 527-537. e) K. J. Butcher, S. M. 
Denton, S. E. Field, A. T. Gillmore, G. W. Harbottle, R. M. Howard, D. A. Laity, C. J. Ngono, B. A. Pibworth, Org. Process Res. Dev. 2011, 15, 1192-1200. f) V. Hickmann, A. Kondoh, B. Gabor, M. Alcarazo, A. Fürstner, J. Am. Chem. Soc. 2011, 133, 13471-13480. g) H. Benelkebir, C. Hodgkinson, P. J. Duriez, A. L. Hayden, R. A. Bulleid, S. J. Crabb, G. Packham, A. Ganesan, Bioorg. Med. Chem. 2011, 19, 3709-3716. h) R. Schiess, J. Gertsch, W. B. Schweizer, K.-H. Altmann, Org. Lett. 2011, 13, 1436-1439. i) S. Hirai, M. Nakada, Tetrahedron 2011, 67, 518-530.

3 For reviews on cyclopropanation and their ring-opening reactions see: a) N. Iwasawa, N. Narasaka, J. Salaun, Small Ring Compounds in Organic Synthesis VI, Topics in Current Chemistry; A. de Meijere, H. Kessler, J. M. Lehn, S. V. Ley, S. L. Schreiber, Eds. Springer: Berlin, 2000, Vol 207. b) O. G. Kulinkovich, Chem. Rev. 2003, 103, 2597-2632. c) M. Yu, B. L. Pagenkopf, Tetrahedron 2005, 61, 321-347. d) M. Rubin, M. Runina, V. Gevorgyan, Chem. Rev. 2007, 107, 3117-3179. e) H. Pellissier, Tetrahedron, 2010, 66, 8341-8375.

4 For recent and selected examples, see: a) T. Ok, A. Jeon, J. Lee, J. H. Lim, C. S. Hong, H.-S. Lee, J. Org. Chem. 2007, 72, 7390-7393. b) M. Tanaka, M. Ubukata, T. Matsuo, K, Yasue, K. Matsumoto, Y. Kajimoto, T. Ogo, T. Inaba, Org. Lett. 2007, 9, 3331-3334. c) T. Tada, Y. Ishida, K. Saigo, Org. Lett. 2007, 9, 2083-2086. d) N. T. Tzvetkov, T. Arndt, J. Mattay, Tetrahedron 2007, 63, 10497-10510. e) S. K. Jackson, A. Karadeolian, A. B. Driega, M. A. Kerr, J. Am. Chem. Soc. 2008, 130, 4196-4201. f) K. Nomura, S. Matsubara, Chem. Eur. J. 2010, 16, 703-708.

5 a) H. Kakei, T. Sone, Y. Sohtome, S. Matsunaga, M. Shibasaki, J. Am. Chem. Soc. 2007, 129, 13410-13411. b) M. Cheeseman, I. R. Davies, P. Axe, A. L. Johnson, S. D. Bull, Org. Biomol. Chem. 2009, 7, 3537-3548. c) D. J. Aitken, S. D. Bull, I. R. Davies, L. Drouin, J. Ollivier, J. Peed, Synlett 2010, 2729-2732. d) T. Goto, K. Takeda, M. Anada, K. Ando, S. Hashimoto, Tetrahedron Lett. 2011, 52, 4200-4203.

6 a) T. Rovis, D. A. Evans, Prog. Inorg. Chem. 2001, 50, 1-150. b) H. M. L. Davies, E. G. Antoulinakis, Org. React. 2001, 57, 1-326. c) V. N. G. Lindsay, W. Lin, A. B. Charette, J. Am. Chem. Soc. 2009, 131, 16383-16385. d) S. R. Goudreau, A. B. Charette, J. Am. Chem. Soc. 2009, 131, 15633-15635. e) M. P. Doyle, Angew. Chem. Int. Ed. 2009, 48, 850-852. f) S. Zhu, X. Xu, J. A. Perman, X. P. Zhang, J. Am. Chem. Soc. 2010, 132, 12796-12799. g) T. Nishimura, Y. Maeda, T. Hayashi, Angew. Chem. Int. Ed. 2010, 49, 7324-7327. h) J.-I. Ito, S. Ujiie, H. Nishiyama, Chem. Eur. J. 2010, 16, 4986-4990. i) V. N. G. Lindsay, C. Nicolas, A. B. Charette, J. Am. Chem. Soc. 2011, 133, 8972-8981. j) X. Xu, H. Lu, J. V. Ruppel, X. Cui, S. Lopez de Mesa, L. Wojtas, X. P. Zhang, J. Am. Chem. Soc. 2011, 133, 15292-15295.

7 a) D. P. Charles, V. L. Steven, J. G. Matthew, Angew. Chem. Int. Ed. 2003, 42, 828831. b) C. D. Papageorgiou, M. A. Cubillo de Dois, S. V. Ley, M. J. Gaunt, Angew. Chem. Int. Ed. 2004, 43, 4641-4644. c) R. K. Kunz, D. W. C. MacMillan, J. Am. Chem. Soc. 2005, 127, 3240-3241. d) H. Xie, L. Li, H. Zu, J. Wang, W. Wang, J. Am. Chem. Soc. 2007, 129, 1088610894. e) R. Rios, H. Sunden, J. Vesely, G. L. Zhao, P. Dziedzic, A. Cordova, Adv. Synth. Catal. 2007, 349, 1028-1032. f) H. Pellissier, Tetrahedron 2007, 63, 9267-9331. g) J. L. Vicario, D. Badia, L. Carrillo, Synthesis 2007, 2065-2092. h) X.-L. Sun, Y. Tang, Acc. Chem. Res. 2008, 41, 937-948. i) Y. Cheng, J. An, L.-Q. Lu, L. Luo, Z.-Y. Wang, J.-R. Chen, W.-J. Xiao, J. Org. Chem. 2011, 76, 281-284. 
8 a) H. Takahashi, M. Yoshioka, M. Shibasaki, M. Ohno, N. Imai, S. Kobayashi, Tetrahedron 1995, 51, 12013-12026. b) S. E. Denmark, B. L. Christenson, S. P. O'Connor, M. Noriaki, Pure Appl. Chem. 1996, 68, 23-27. c) S. E. Denmark, S. P. O'Connor, J. Org. Chem. 1997, 62, 3390-3401. f) J. Balsells, P. J. Walsh, J. Org. Chem. 2000, 65, 5005-5008. d) A. B. Charette, C. Molinaro, C. Brochu, J. Am. Chem. Soc. 2001, 123, 12168-12175. e) J. Long, Y. Yuan, Y. Shi, J. Am. Chem. Soc. 2003, 125, 13632-13633. f) J. Long, H. Du, K. Li, Y. Shi, Tetrahedron Lett. 2005, 46, 2737-2740. g) A. Voituriez, A. B. Charette, Adv. Synth. Catal. 2006, 348, 2363-2370. h) A. B. Charette, In The Chemistry of Organozinc Compounds, Z. Rappoport, I. Marek, Eds. John Wiley \& Sons, Ltd.: West Sussex, 2006, pp 237-286. i) H. Shitama, T. Katsuki, Angew. Chem. Int. Ed. 2008, 47, 2450-2453. j) L. E. Zimmer, A. B. Charette, J. Am. Chem. Soc. 2009, 131, 15624-15626. k) S. R. Goudreau, A. B. Charette, J. Am. Chem. Soc. 2009, 131, 15633-15635. m) L.-P. B. Beaulieu, L. E. Zimmer, A. B. Charette, Chem. Eur. J. 2009, 15, 11829-11832. n) J. M. Concellon, H. Rodriguez-Solla, C. Concellon, V. del Amo, Chem. Soc. Rev. 2010, 39, 4103-4113.

9 Emschwiller, G. Compt. Rend. 1929, 188, 1555-1557.

10 a) H. E. Simmons, R. D. Smith, J. Am. Chem. Soc. 1958, 80, 5323-5323. b) H. E. Simmons, R. D. Smith, J. Am. Chem. Soc. 1959, 81, 4256-4264.

11 For the first reports on the directing ability of hydroxyl groups, see: a) Winstein, S. Sonnenberg, J. De Vries, L. J. Am. Chem. Soc. 1959, 81, 6523-6524. b) Dauben, W. G. Berezin, G. H. J. Am. Chem. Soc. 1963, 85, 468-472.

12 a) H. Hermann, J. C. W. Lohrenz, A. Kühn, G. Boche, Tetrahedron 2000, 56, 41094115. b) W.-H. Fang, D. L. Phillips, D.-Q. Wang, Y.-L. Li, J. Org. Chem. 2002, 67, 154-160.

13 M. Ratier, M. Castaing, J.-Y. Godet, M. Pereyre, J. Chem. Res.(M) 1978, 2309-2318.

14 A. B. Charette, H. Lebel, J. Org. Chem. 1995, 60, 2966-2967.

15 H. Shitama, T. Katsuki, Angew. Chem. Int. Ed. 2008, 47, 2450-2453.

16 a) H. Y. Kim, A. E. Lurain, P. García-García, P. J. Carroll, P. J. Walsh, J. Am. Chem. Soc. 2005, 127, 13138-13139. b) H. Y. Kim, L. Salvi, P. J. Carroll, P. J. Walsh, J. Am. Chem. Soc. 2009, 131, 954-962. c) H. Y. Kim, L. Salvi, P. J. Carroll, P. J. Walsh, J. Am. Chem. Soc. 2010, 132, 402-412. d) H. Y. Kim, J. Walsh Acc. Chem. Res. 2012, 45, 1533-1547

17 a) C. Andrés, J. Nieto, R.1 Pedrosa, and M. Vicente, J. Org Chem. 1998, 63, 8570-8573. b) C. Andrés, M. García-Valverde, J. Nieto, R. Pedrosa J. Org Chem. 1999, 64, 5230-5236 c) C. Andrés, J. P. Duque-Soladana, R. Pedrosa, J. Org Chem. 1999, 64, 4273-4281. d) R. Pedrosa, C. Andrés, J. Nieto, S. del Pozo, J. Org Chem. 2003, 68, 4923-4931. e) R. Pedrosa, C. Andrés, L. Martín, J. Nieto, J. Org. Chem. 2005, 70, 4332-4337.f) R. Pedrosa, C. Andrés, A. GutierrezLoriente, J. Nieto, Eur. J. Org. Chem. 2005, 2449-2458. g) R. Pedrosa, C. Andrés, J. Nieto, C. Pérez-Cuadrado, I. San Francisco, Eur. J. Org. Chem. 2006, 3259-3265. h) R. Pedrosa, C. Andrés, P. Mendiguchía, and J. Nieto, J. Org. Chem. 2006, 71, 8854-8863.

18 a) C. Andrés, R. Infante, J. Nieto, Tetrahedron: Asymmetry 2010, 21, 2230-2237. b) R. Infante, J. Nieto, C. Andrés, Org. Biomol. Chem. 2011, 9, 6691-6699. c) R. Infante, J. Nieto, C. Andrés, Synthesis 2012, 44, 1343-1348; d) R. Infante, J. Nieto, C. Andrés, Chem. Eur. J. 2012, 
18, 4375-4379; e) R. Infante, A. Gago, J. Nieto, C. Andrés, Adv. Synth. Catal. 2012, 354, $2797-$ 2804.

19 For the synthesis of ligand 1 see ref 18a and: a) R. Pedrosa, C. Andrés, C. D. Rosón, M. Vicente, J. Org. Chem. 2003, 68, 1852-1858. b) C. Andrés, I. González, J. Nieto, C. D. Rosón, Tetrahedron 2009, 65, 9728-9736.

20 For the synthesis of 1,1-diiodoethane see: E. C. Friedrich, S. N. Falling, D. E. Lyons, Synth. Commun. 1975, 5, 33-36.

21 C. Jimeno, S. Sayalero, T. Fjermestad, G. Colet, F. Maseras, M. A. Pericàs, Angew. Chem. Int. Ed. 2008, 47, 1098-1101.

22 H. Kakei, T. Sone, Y. Sohtome, S. Matsunaga, M. Shibasaki, J. Am. Chem. Soc. 2007, $129,13410-13411$

23 R. Pedrosa, C. Andres, J. Nieto, J. Org. Chem. 2002, 67, 782-789.

24 X. Wu, X. Liu, G. Zhao, Tetrahedron: Asymmetry 2005, 16, 2299-2305. 